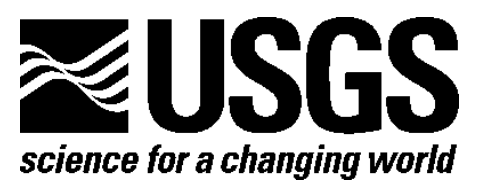

\title{
Summary of the Ahankashan Area of Interest
}

By Lawrence J. Drew, David M. Sutphin, John C. Mars, and Anya K. Bogdanow

Open-File Report 2015-1040

USGS Afghanistan Project Product No. 305

U.S. Department of the Interior

U.S. Geological Survey 


\section{U.S. Department of the Interior SALLY JEWELL, Secretary}

\section{U.S. Geological Survey \\ Suzette M. Kimball, Acting Director}

U.S. Geological Survey, Reston, Virginia: 2015

For more information on the USGS-the Federal source for science about the Earth, its natural and living resources, natural hazards, and the environment-visit http://www.usgs.gov or call 1-888-ASK-USGS (1-888-275-8747)

For an overview of USGS information products, including maps, imagery, and publications, visit http://www.usgs.gov/pubprod

To order this and other USGS information products, visit http://store.usgs.gov

Any use of trade, firm, or product names is for descriptive purposes only and does not imply endorsement by the U.S. Government.

Although this information product, for the most part, is in the public domain, it also may contain copyrighted materials as noted in the text. Permission to reproduce copyrighted items must be secured from the copyright owner.

Suggested citation:

Drew, L.J., Sutphin, D.M., Mars, J.C., and Bogdanow, A.K., 2015, Summary of the Ahankashan area of interest: U.S. Geological Survey Open-File Report 2015-1040, 26 p., http://dx.doi.org/10.3133/ofr20151040.

ISSN 2331-1258 (online) 


\section{Contents}

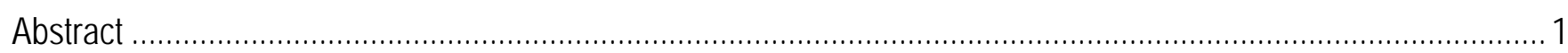

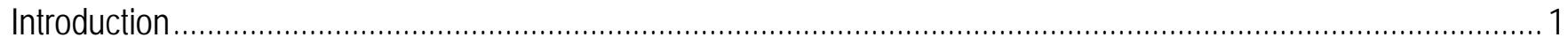

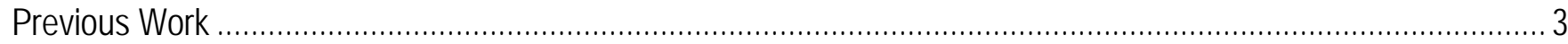

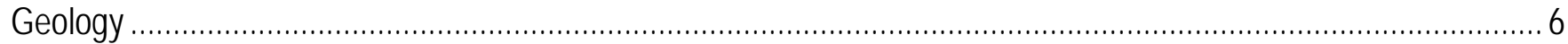

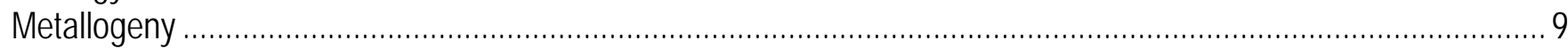

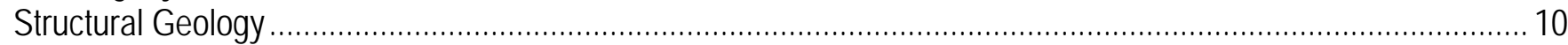

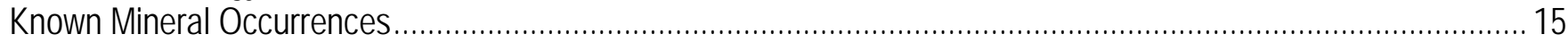

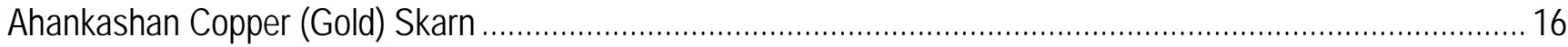

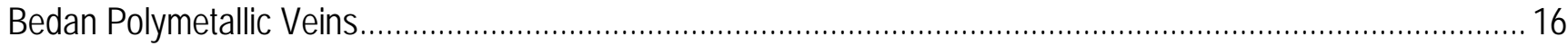

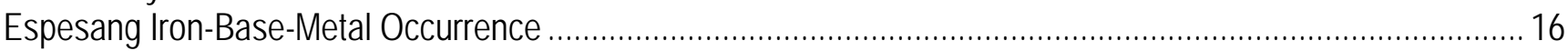

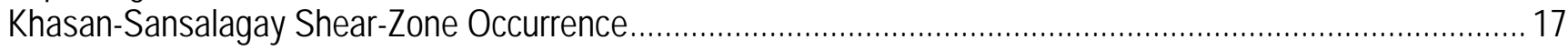

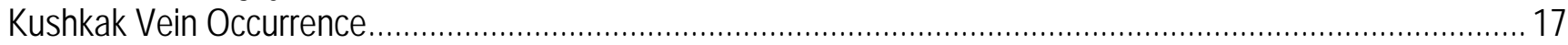

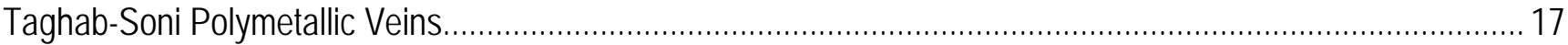

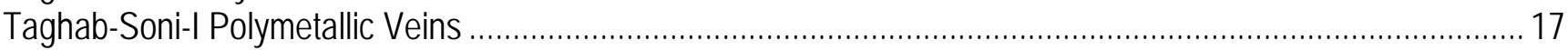

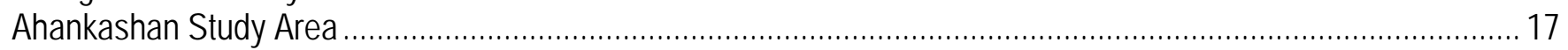

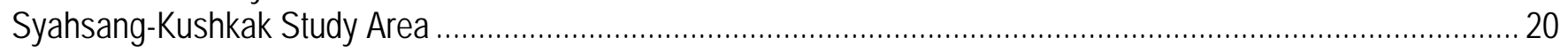

Taghab-Soni Study Area

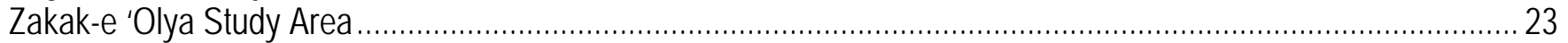

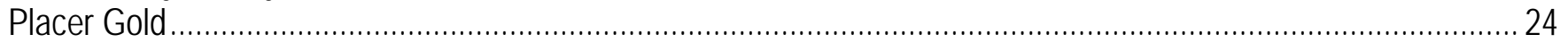

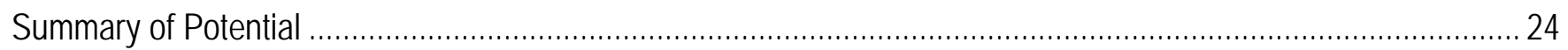

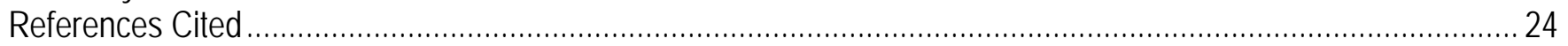

\section{Figures}

1. Map of the location of the Ahankashan Area of Interest, the new areas of interest, and the other areas of interest in Afghanistan.

2. Map of the locations of the four mineral-resource study areas in the Ahankashan Area of Interest and the hydrothermal alteration zones .............................................................................................. 3

3. Geologic map of the Ahankashan Area of Interest, including the study areas and locations of the known

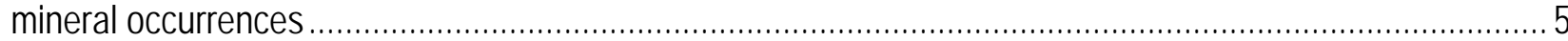

4. Map of the metallogenic domains, known mineral occurrences, major fault zones, provincial boundaries, and the distribution of intrusive rocks in the Ahankashan Area of Interest ............................................ 6

5. Map of the thrust faults that are associated with Miocene granitic intrusions in the Ahankashan Area of Interest ........................................................................................................................ 11

6. Map of the Triassic, Cretaceous, Paleocene, and Eocene sedimentary rocks and thrust fault traces that are associated with Miocene granitic intrusions in the Ahankashan Area of Interest ..

7. Map of the right-lateral strike-slip faults; Triassic, Cretaceous, Paleocene, and Eocene sedimentary rocks; and thrust faults that are associated with Miocene granitic intrusions in the Ahankashan Area of Interest......

8. Map of the Miocene granitic intrusions; right-lateral strike-slip faults; Triassic, Cretaceous, Paleocene, and Eocene sedimentary rocks; and thrust fault traces associated with Miocene granitic intrusions in the Ahankashan Area of Interest.

9. Cross section of the Ahankashan Area of Interest along line $A-A$ ' from figure 8 showing the topographic profile in kilometers, Miocene thrust faults, strike-slip faults, and a Miocene granodioritic intrusion. 
10. Map of the diorite intrusives in the Ahankashan copper skarn study area.

11. Map of the hydrothermal alteration zones, location of the diorite intrusive, the skarn, and the surrounding area of the Ahankashan copper skarn study area

12. Map of the hydrothermal alteration zones and the location of the Miocene intrusions in the SyahsangKushkak subarea of the Ahankashan Area of Interest

13. Map of the hydrothermal alteration zones and geology in the Taghab-Soni subarea of the Ahankashan Area of Interest................................................................................................................. 22

14. Map of the hydrothermal alteration zones and geology of the Zakak-e 'Olya subarea of the Ahankashan Area of Interest.....

\section{Tables}

1. Stratigraphic rock units of the Ahankashan Area of Interest.

2. Selected characteristics of the known nonfuel mineral occurrences of the Ahankashan Area of Interest. 


\title{
Summary of the Ahankashan Area of Interest
}

\author{
By Lawrence J. Drew, David M. Sutphin, John C. Mars, and Anya K. Bogdanow
}

\begin{abstract}
This report summarizes and interprets results of the work in the Ahankashan Area of Interest in northwestern Afghanistan and four study areas-the Ahankashan Prospect Area, Syahsang-Kushkak, Taghab-Soni, and Zakak-e 'Olya-delineated for their potential undiscovered mineral occurrences with specific emphasis on porphyry copper and related occurrence types. The area of interest is underlain by rocks of three different geologic domains that cross from east to west - the Band-e-Bayan Block/Central Pamirs Domain in the south, the Hindu Kush Domain in the Paropamisus Mountains, and the Afghan Turkestan Domain in the north. The domains are sutured remnants of Tethyan tectonic elements. Interpretation of the geologic maps indicates the presence of thrust faults, strike-slip faults, and granitic intrusions emplaced in ground prepared by faulting. Thrust faulting was followed by strike-slip faulting and then followed by magmatic intrusions. Advanced Spaceborne Thermal Emission and Reflection Radiometer data were used to map minerals that have been altered by hydrothermal fluids typically associated with mineralization to delineate new potential occurrences of copper, gold, and silver. Propylitic-, argillic-, and phyllic-altered intrusive rocks are found in the area, as well as very minor amounts of hydrothermal silica-rich rocks. This area of interest is vastly underexplored and contains only seven known mineral occurrences, of which the Ahankashan copper (gold) skarn occurrence is the best known. Gold has been found in stream sediments near the Ahankashan skarn, in the Taghab-Soni study area, and possibly other parts of the area of interest, suggesting potential for at least small-scale placer occurrences.
\end{abstract}

\section{Introduction}

The Ahankashan Area of Interest (AOI) is in northwestern Afghanistan about 100 to 240 kilometers $(\mathrm{km})$ east of Herat along the Herat fault, a major east-west right-lateral strike-slip fault (fig. 1). It incorporates parts of the Feroz Koh tract (ppycu08) of Peters and others (2007) and Ludington and others (2007); the large northeast-trending appendage of that tract is not considered in this report. The AOI contains the Ahankashan, Syahsang-Kushkak, Taghab-Soni, and Zakak-e 'Olya (fig. 2) study areas, selected for their distinctive geologic setting and mineral associations that may offer enhanced potential for undiscovered mineral occurrences. The Ahankashan study area, in the northeast quadrant of the AOI, contains the Ahankashan copper (gold) skarn occurrence that was systematically mapped and explored by Soviet and Afghan geologists in the 1970s. Anomalous gold, copper, molybdenum, lead, and arsenic were identified in the vicinity of the skarn occurrence (Shcherbina and others, 1974a,b; Abdullah and others, 1977; Ludington and others, 2007). The Syahsang-Kushkak study area, which is in the southeast quadrant of the AOI, contains the Kushkak bedded barite occurrence and a string of several Miocene intermediate to granitic intrusions that form a northeast-southwest arc across the study area (Debon and others, 1987; Doebrich and Wahl, 2006). These intrusions are reported to be similar to the body that hosts the Ahankashan copper (gold) skarn occurrence and the intrusive rocks in 
the Zakak-e 'Olya study area (Shcherbina and others, 1974a,b). Mars (2012) identified areas of phyllic and argillic alteration related to the intrusions in the study area.

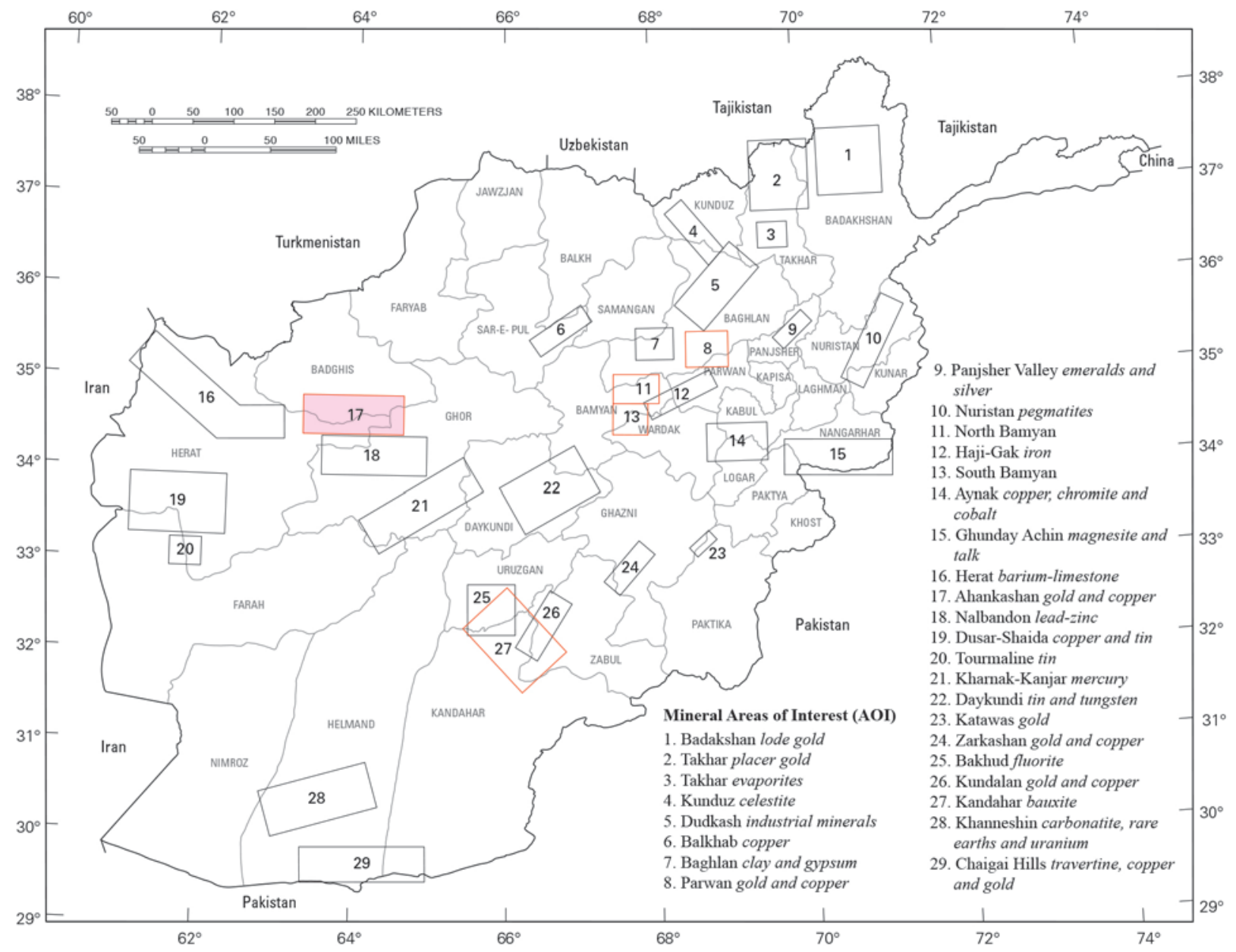

Figure 1. The location of the Ahankashan Area of Interest (shown with red fill), the new areas of interest (outlined in red), and the other areas of interest in Afghanistan (outlined in black). 


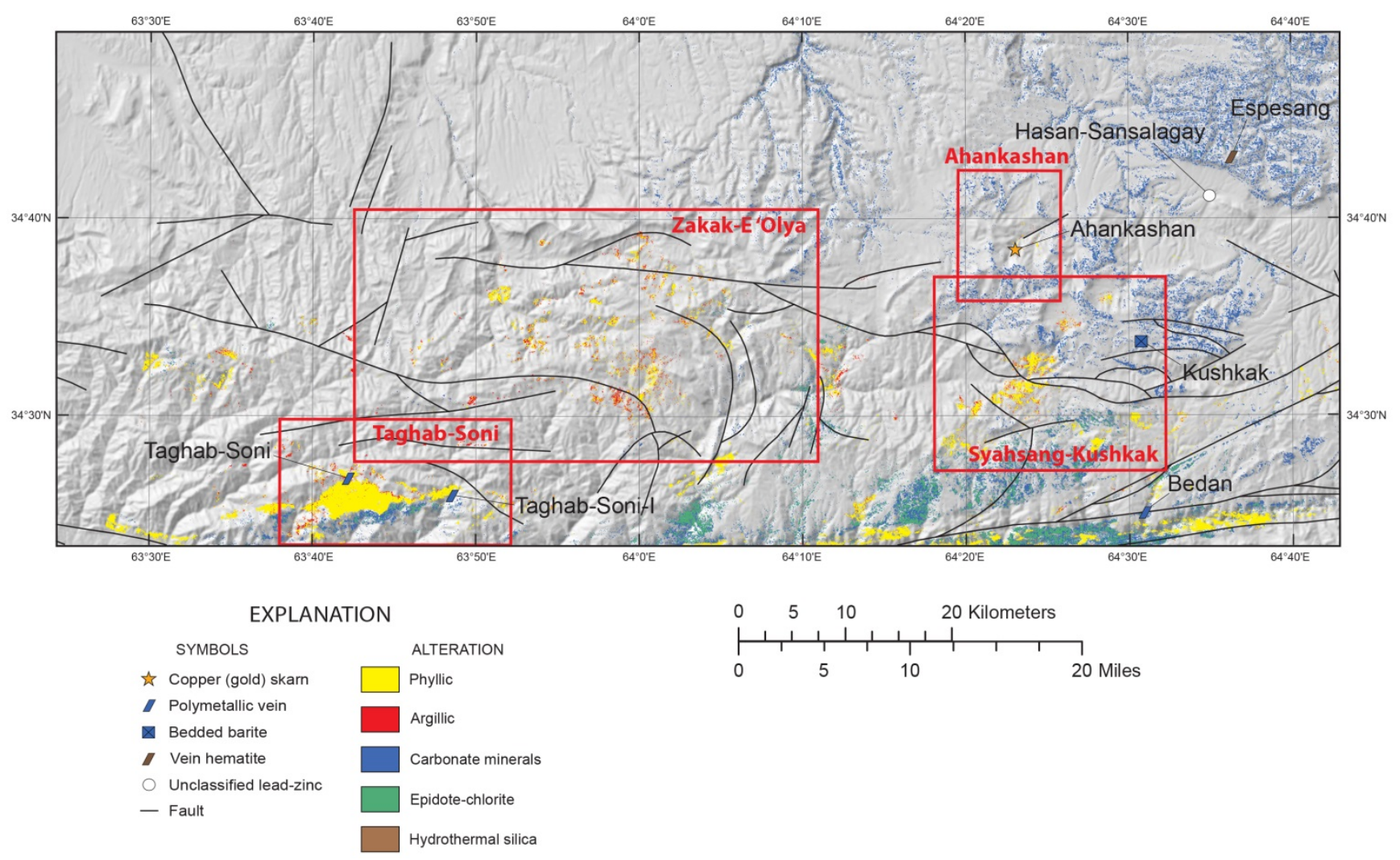

Figure 2. Locations of the four mineral-resource study areas in the Ahankashan Area of Interest (outlined in red) and the hydrothermal alteration zones. Alteration data are described in Mars (2012).

The Taghab-Soni study area, which is in the southwestern part of the AOI, is the site of two polymetallic vein occurrences near the contact between a Late Triassic granitic intrusion and Late Carboniferous terrigenous carbonate and clastic sedimentary rocks and mafic volcanic rocks. Along the contact, the granitic rocks have undergone intense phyllic alteration as identified from satellite images (Mars, 2012). The Zakak-e 'Olya study area contains a cluster of Miocene intermediate to granitic intrusions in the center of the AOI. The host rocks for these intrusions are Middle to Late Triassic clastic and carbonate sedimentary rocks with felsic to mafic volcanic rocks. Scattered areas of intense phyllic and argillic alteration were identified near the intrusions (Mars, 2012). This report summarizes the published and unpublished work on the economic geology of the AOI and its study areas, as well as a brief summary of the potential for future discoveries. As of spring 2013, no field visits by U.S. Geological Survey scientists have been made to the Ahankashan AOI.

\section{Previous Work}

In 1967, a geological investigation of Afghanistan was begun by Soviet and Afghan scientists with the purpose of mapping the country at a scale of 1:500,000 with prospective areas mapped in more detail. By 1971, geological mapping and prospecting had begun in Ahankashan; the stratigraphy, magmatism, and tectonics were investigated; and occurrences of gold, mercury, and base metals were identified with the most prospective occurrences receiving further investigation (Shcherbina and others, 1974a,b). Among the products of this work were identification of copper-gold-bearing rocks at Ahankashan and other areas, mapping of numerous small Miocene intrusions where the Murgab and the Hari-Rud Rivers approach one another, the recognition of widely developed hydrothermal alteration 
within a granodiorite-diorite porphyry intrusion in the streambed at Ahankashan, and indications of old mining activity in the Ahankashan area (Shcherbina and others, 1974a,b).

In 1972, the so-called Adreskan crew, which consisted of geologists of the Afghanistan Ministry of Mines and Industries with technical assistance from scientists from the Soviet Union, explored and evaluated the Ahankashan area and adjoining regions in the headwaters of the Murgab River and part of Badghis Province for the presence of copper and gold mineralization (Shcherbina and others, 1974a,b). Until then, geological investigation in the area had not been detailed, so no data on its structure and mineral resources were available.

The Adreskan crew mapped the geology of the area around the Ahankashan copper (gold) occurrence at a scale of 1:12,000, collected geochemical samples, and performed analyses of heavymineral stream-sediment concentrates (Shcherbina and others, 1974a,b). Anomalous gold, copper, molybdenum, lead, and arsenic were identified in the area around the Ahankashan copper (gold) occurrence. Old metals workings were sampled in the vicinity of the Ahankashan occurrence, and locally, the rocks were mapped at a scale of 1:1,000 in several trenches. Likewise, the description of the Ahankashan occurrence by Abdullah and others (1977) speculated that an identified stockwork and veinlets and the presence of the copper (gold) skarn occurrence may be related to porphyry copper-style mineralization.

A preliminary mineral resource assessment of selected mineral occurrence types in Afghanistan by the U.S. Geological Survey (USGS) delineated a resource-assessment tract (ppycu08) in this region that included both arcs of Triassic and Miocene intermediate to felsic igneous rocks and the Ahankashan copper (gold) skarn occurrence (Ludington and others, 2007). The assessment was based on interpretation of published and unpublished Afghan reports, limited in-country reconnaissance field trips, and the presence of mapped Miocene intrusive rocks (map unit $\mathbf{N}_{\mathbf{1}}$ dig in figure 3 ) that suggested the presence of porphyry-style mineralization even though the tract contained no known porphyry copper occurrences (Doebrich and Wahl, 2006). These rocks consist of diorite, granodiorite, monzonite, syenite, and porphyritic nepheline syenite. The preliminary assessment proposed that the erosion level in the region may not be deep enough to expose a porphyry environment, and thus, any occurrences may be hidden. A quantitative assessment that uses the USGS three-part assessment methodology estimated the following: a 90 -percent chance of 0 or more undiscovered porphyry copper occurrences, a 50-percent chance of 0 or more undiscovered porphyry copper occurrences, and a 10-percent chance of 2 or more undiscovered porphyry copper occurrences (Ludington and others, 2007). The mean amounts of contained metal that result from the Monte Carlo simulation based on these estimated probabilities of occurrence are 2 million tons (Mt) copper, 50,000 tons (t) molybdenum, $48 \mathrm{t}$ gold, and $670 \mathrm{t}$ silver in a 400-Mt porphyry copper occurrence. 

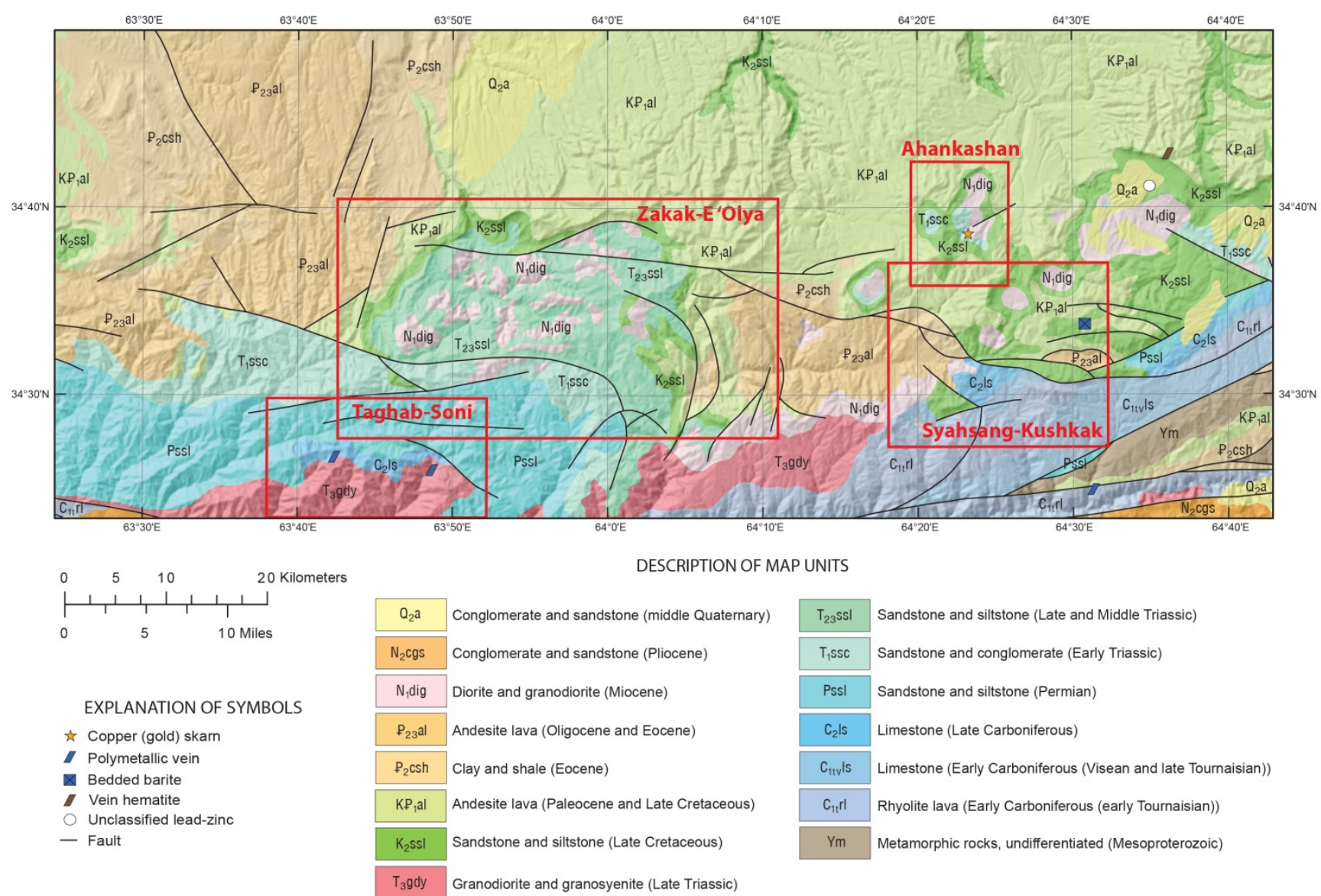

Figure 3. Geologic map of the Ahankashan Area of Interest (Doebrich and Wahl, 2006), including the study areas (outlined in red) and locations of the known mineral occurrences. Explanations of rock units are given in table 1.

Doebrich and others (2007) and Ludington and others (2007) identified Triassic, Cretaceous, and Paleocene to Miocene Tethyan magmatic arcs in Afghanistan. The arcs are represented by intrusive and volcanic rocks where porphyry copper occurrences may occur. A synthesis of geological, mineral occurrence, aerogeophysical, remote sensing, and geochemical data delineated regions in which the occurrence of porphyry copper occurrences are possible. Included in the discussion was the coppergold-molybdenum stockwork at Okhankoshan (Ahankashan) associated with Oligocene and Miocene granitic rocks and coeval volcanic rocks. At that time it was not clear how the Okhankoshan occurrence related to the Ahankashan occurrence, so the Ahankashan AOI was not defined in Peters and others (2007). The Okhankoshan is a copper skarn to the north of the Ahankashan AOI, located in the northern part of the Feroz Koh permissive tract (ppycu08).

Advanced Spaceborne Thermal Emission and Reflection Radiometer (ASTER) data were used for an analysis of the Ahankashan AOI by Mars (2012) to map minerals that are typically associated with hydrothermal alteration to delineate new potential occurrences of copper, gold, and silver. Mars (2012) identified an area of propylitic- (epidote, chlorite, and carbonate), argillic-, and phyllic-altered intrusive rocks in the area with very minor amounts of hydrothermal silica-rich rocks. Minor argillic and phyllic alterations at the Ahankashan copper (gold) skarn occurrence were identified by using ASTER data (Mars, 2012). Most of the Miocene intrusive rocks near the Herat fault zone show mixed patterns of argillic- and phyllic-altered rocks. The Triassic granodiorite intrusive that contains two polymetallic 
vein occurrences, Taghab Soni and Taghab Soni-I, along the Herat fault exhibits zoned propylitic-, argillic- and phyllic-altered rocks that are typically associated with porphyry copper occurrences (John and others, 2010). Analysis of the ASTER data shows that most of the hydrothermally altered intrusive rocks are located in the central part of the study area near the Herat fault zone (Mars, 2012).

\section{Geology}

The Ahankashan AOI is a roughly 50-km-wide and 135-km-long rectangle with an area of 6,415 square kilometers $\left(\mathrm{km}^{2}\right)$ located in Northern Afghanistan. It includes, from south to north, a sliver of the Band-e-Bayan Block/Central Pamirs Domain south of the Herat fault zone, a section of the Hindu Kush Domain in the Paropamisus Mountains north of the fault zone, and a small part of the Afghan Turkestan Domain south of the Band-e Turkestan Mountains (fig. 4; Montenat, 2009).

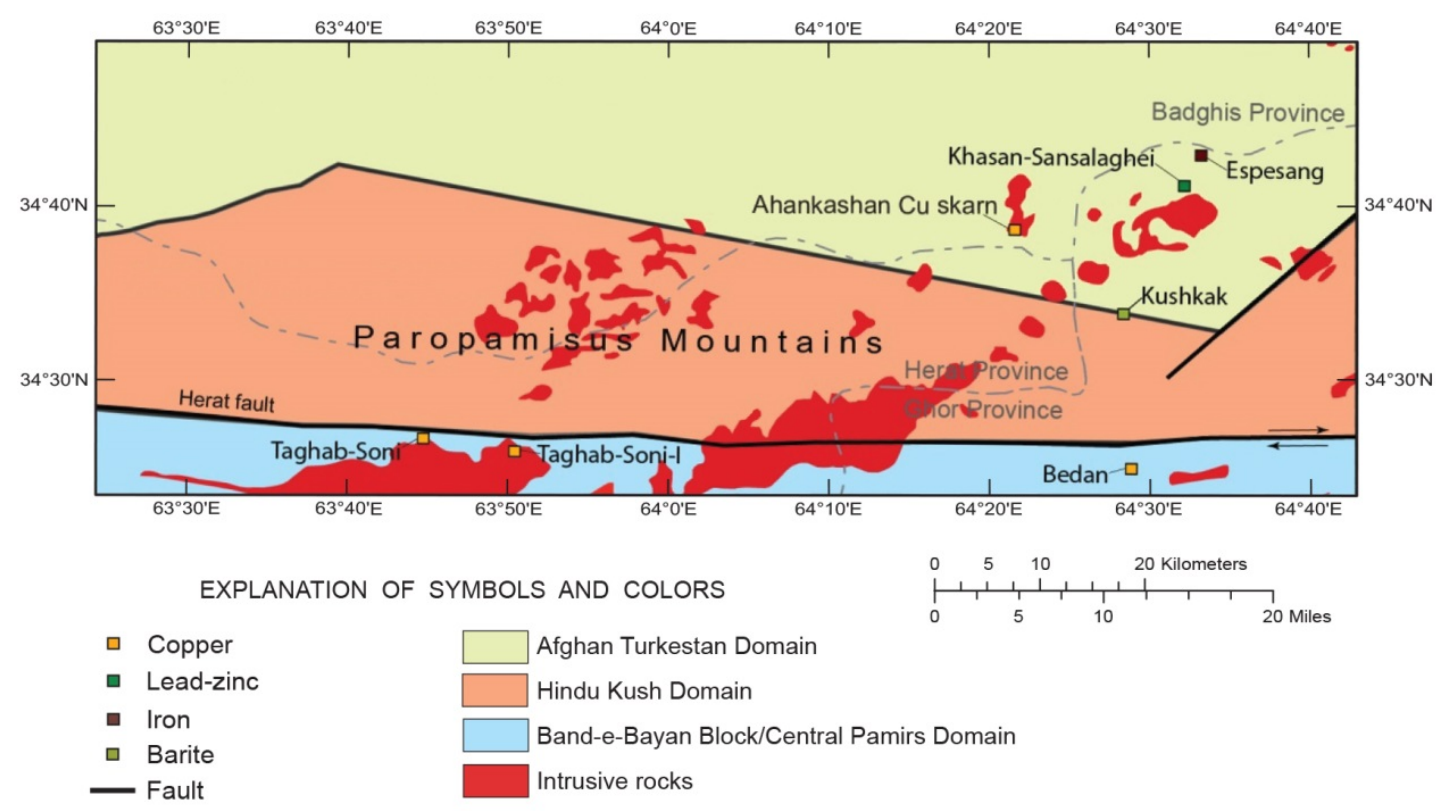

Figure 4. Metallogenic domains, known mineral occurrences, major fault zones, provincial boundaries, and the distribution of intrusive rocks in the Ahankashan Area of Interest (Montenat, 2009).

In the northern part of the AOI, the Afghan Turkestan Domain is underlain by part of the Hercynian Orogen of Central Asia, which is a heterogeneous mass that comprises several uplifted or depressed blocks that are reflected in the thickness and facies variations in the Mesozoic and the Cenozoic cover rocks (fig. 4; Montenat, 2009). It is separated from the Hindu Kush Domain on the south by an East-West trending fault system. The Ahankashan copper (gold) skarn occurrence is found in the Afghan Turkestan Domain, and the Kushkak bedded barite occurrence is located in or close to this fault system.

The central geologic domain in the AOI is the Hindu Kush Domain, which was derived from the Hercynian Orogen that stretches almost uninterrupted from Tajikistan in the east to beyond Herat in the west and into Iran. This domain contains the Paropamisus Mountains and is bounded on the south by the Herat fault, which is interpreted as a suture that resulted from the closing of the Hercynian Paleo-Tethys Ocean (Karapetov and others, 1975; Stöcklin, 1977; Ludington and others, 2007; Montenat, 2009; Okaya and others, 2009). The Hindu Kush Domain was affected by Triassic-Jurassic Cimmerian tectonics and magmatic events (Montenat, 2009). In the AOI, the Hindu Kush Domain has been 
intruded by numerous stocks of Miocene granitic rocks. None of the seven known mineral occurrences in the AOI occurs in the Hindu Kush Domain.

The Band-e-Bayan Block/Central Pamirs Domain lies south of the Herat fault. Little is known about this thin, complexly structured block other than it has a Proterozoic core similar to that of the Central Mountains (Montenat, 2009). Within the Band-e-Bayan Block east of the AOI, the Haji-Gak iron occurrence is located in a thick volcanic sedimentary series within a sequence of Lower Paleozoic calcareous and detrital sedimentary rocks (Montenat, 2009; Sutphin and others, 2011). Outside of the AOI, the Band-e-Bayan Block was a region of reduced sedimentation or was subaerially exposed as indicated by zones of bauxite (Montenat, 2009). During the Triassic, calc-alkaline granodiorites were intruded into the central part of the western Hindu Kush (fig. 4; Montenat, 2009). These intrusions occur as two large igneous masses in the southern Ahankashan AOI along and north of the Herat fault. The only reported mineral occurrences in the Band-e-Bayan Block/Central Pamirs Domain part of the AOI are the Bedan, the Taghab-Soni, and the Taghab-Soni-I polymetallic veins, the latter two of which are Late Triassic in age.

Boyd and others (2007) described the Herat fault as a 730-km-long right-lateral strike-slip fault that extends from its intersection with the Chaman fault north of Kabul westward to the Iran border. The fault is an easily identified geomorphic landmark partly because of the region's arid climate and because much of the fault is located in hard bedrock, but evidence for active faulting remains controversial (Wellman, 1965; Trifonov, 1978; Boyd and others, 2007). Sborshchikov and others (1981) reported that the fault appears to have laterally offset stream channels by $5 \mathrm{~km}$ since the Late Pliocene (about 2 million years ago), thus resulting in a long-term average slip rate of about 3 millimeters per year (mm/yr), whereas Boyd and others (2007) modeled a modest slip rate of $2 \mathrm{~mm} / \mathrm{yr}$.

During the Miocene, diorite and granodiorite intrusions $\left(\mathbf{N}_{\mathbf{1}} \mathbf{d i g}\right)$ were emplaced into the Permian sedimentary and mafic volcanic formations (Pssl), Triassic volcano-sedimentary rocks $\left(\mathbf{T}_{\mathbf{1}} \mathbf{s s c}\right)$, and Cretaceous to Paleocene sedimentary formations $\left(\mathbf{K}_{2} \mathbf{s s l}\right)$ in the central and eastern parts of the AOI (fig. 3; table 1; Shcherbina and others, 1974a,b). In several places in the AOI, these intrusions form domed stocklike bodies. In some domes, folding and erosion have brought the intrusion and underlying stratified formations to the surface, thus forming a characteristic bulls-eye geologic map pattern with the intrusion at the center. In other domes, the intrusion is not exposed, and only the domed stratified Triassic and Cretaceous formations are seen poking through the younger sedimentary formations $\left(\mathbf{K}_{2} \mathbf{s s l}\right)$. The Ahankashan copper (gold) skarn occurrence is located in one of the bulls-eye-type domes near the contact between the Miocene intrusion and the domed Triassic sedimentary-volcanic rocks ( $\left.\mathbf{T}_{1} \mathbf{s s c}\right)$ (table 1).

Table 1. Stratigraphic rock units of the Ahankashan Area of Interest (Chmyriov and Mirzad, 1972; Doebrich and Wahl, 2006). Rock units are shown in figure 3.

\begin{tabular}{|c|c|c|c|}
\hline Unit label & Age & General rock type & Rocks \\
\hline \multicolumn{4}{|c|}{ CENOZOIC } \\
\hline \multicolumn{4}{|c|}{ Quaternary } \\
\hline $\mathbf{Q}_{2} \mathbf{a}$ & Middle Quaternary & $\begin{array}{l}\text { Stratified } \\
\text { sedimentary/ } \\
\text { volcanic }\end{array}$ & $\begin{array}{l}\text { Shingly and detrital sediments, gravel, sand, clay, clay sand, } \\
\text { loam, loess, travertine, trachybasalt, leucite basanite } \\
\text { (Sarlog Group), andesitic basalt, olivine basalt (Asparan } \\
\text { Group). }\end{array}$ \\
\hline \multicolumn{4}{|c|}{ Tertiary } \\
\hline \multicolumn{4}{|c|}{ Neogene } \\
\hline $\mathrm{N}_{2} \mathrm{cgs}$ & $\begin{array}{l}\text { Pliocene, } \\
\text { undifferentiated }\end{array}$ & $\begin{array}{l}\text { Stratified } \\
\text { sedimentary/ } \\
\text { volcanic }\end{array}$ & $\begin{array}{l}\text { Gray conglomerate, gravelstone, sandstone, siltstone, clay, } \\
\text { limestone, marl, gypsum, salt, acid and mafic volcanic } \\
\text { rocks. }\end{array}$ \\
\hline
\end{tabular}


Table 1. Stratigraphic rock units of the Ahankashan Area of Interest (Chmyriov and Mirzad, 1972; Doebrich and Wahl, 2006). Rock units are shown in figure 3.-Continued

\begin{tabular}{|c|c|c|c|}
\hline Unit label & Age & General rock type & Rocks \\
\hline \multicolumn{4}{|c|}{ Tertiary-continued } \\
\hline \multicolumn{4}{|c|}{ Neogene_-continued } \\
\hline $\mathrm{N}_{1}$ dig & Miocene & Intrusive & $\begin{array}{l}\text { Diorite porphyry, granodiorite porphyry, monzonite } \\
\text { porphyry, syenite porphyry, nepheline syenite. }\end{array}$ \\
\hline \multicolumn{4}{|r|}{ Paleogene } \\
\hline $\mathbf{P}_{23}$ al & Eocene to Oligocene & $\begin{array}{l}\text { Stratified } \\
\text { sedimentary/ } \\
\text { volcanic }\end{array}$ & $\begin{array}{l}\text { Andesitic basalt, basalt, trachyte, dacite, rhyolite, ignimbrite, } \\
\text { tuff, conglomerate, sandstone, siltstone, limestone. }\end{array}$ \\
\hline $\mathbf{P}_{2} \mathbf{c s h}$ & Eocene & $\begin{array}{l}\text { Stratified } \\
\text { sedimentary/ } \\
\text { volcanic }\end{array}$ & $\begin{array}{l}\text { Clay, shale, siltstone, sandstone, limestone, marl, gypsum, } \\
\text { conglomerate (northern Afghanistan-Katavaz Basin), } \\
\text { sandstone, siltstone, conglomerate and gravelstone, acid } \\
\text { and mafic volcanic rocks (Gerirud Basin). }\end{array}$ \\
\hline \multicolumn{4}{|c|}{ MESOZOIC } \\
\hline \multicolumn{4}{|c|}{ Cretaceous } \\
\hline $\mathbf{K} \mathbf{P}_{1} \mathbf{a l}$ & $\begin{array}{l}\text { Late Cretaceous } \\
\text { (Maestrichtian) to } \\
\text { Paleocene }\end{array}$ & $\begin{array}{l}\text { Stratified } \\
\text { sedimentary }\end{array}$ & $\begin{array}{l}\text { Limestone, marl, dolomite, sandstone, clay, siltstone, } \\
\text { gypsum, conglomerate. }\end{array}$ \\
\hline $\mathbf{K}_{2} \mathbf{s s l}$ & $\begin{array}{l}\text { Late Cretaceous, } \\
\text { undifferentiated }\end{array}$ & $\begin{array}{l}\text { Stratified } \\
\text { sedimentary }\end{array}$ & $\begin{array}{l}\text { Sandstone, siltstone, clay, limestone, marl, conglomerate, } \\
\text { gypsum (northern Afghanistan), limestone (central } \\
\text { Afghanistan), redstone, siltstone, conglomerate (Khashrud } \\
\text { Tectonic Zone). }\end{array}$ \\
\hline \multicolumn{4}{|c|}{ Triassic } \\
\hline $\mathbf{T}_{3}$ gdy & Late Triassic & Intrusive & Granodiorite, granosyenite, granophyre, granite. \\
\hline $\mathbf{T}_{23} \mathrm{ssl}$ & $\begin{array}{l}\text { Middle to Late } \\
\text { Triassic }\end{array}$ & $\begin{array}{l}\text { Stratified } \\
\text { sedimentary/ } \\
\text { volcanic }\end{array}$ & $\begin{array}{l}\text { Sandstone, siltstone, mudstone, carbonaceous shale, } \\
\text { limestone, marl, conglomerate, acid and mafic volcanic } \\
\text { rocks (northern Afghanistan), variegated sandstone, } \\
\text { gravelstone, conglomerate, chert, acid and mafic volcanic } \\
\text { rocks (northern Afghanistan), limestone, dolomite, marl } \\
\text { (Kabul Massif and Kunar Tectonic Zone). }\end{array}$ \\
\hline $\mathbf{T}_{1} \mathbf{s S C}$ & Early Triassic & $\begin{array}{l}\text { Stratified } \\
\text { sedimentary/ } \\
\text { volcanic }\end{array}$ & $\begin{array}{l}\text { Limestone, dolomite, marl (Gelmend-Argandab Uplift), } \\
\text { variegated sandstone, gravelstone, conglomerate, chert, } \\
\text { acid and mafic volcanic rocks (northern Afghanistan). }\end{array}$ \\
\hline \multicolumn{4}{|c|}{ PALEOZOIC } \\
\hline \multicolumn{4}{|c|}{ Permian } \\
\hline Pssl & $\begin{array}{l}\text { Permian, } \\
\text { undifferentiated }\end{array}$ & $\begin{array}{l}\text { Stratified } \\
\text { sedimentary/mafic } \\
\text { volcanic }\end{array}$ & $\begin{array}{l}\text { Redstone and variegated sandstone, siltstone, mudstone, } \\
\text { conglomerate, gravelstone (northwestern Afghanistan), } \\
\text { limestone, dolomite, sandstone, siltstone, shale, phyllite, } \\
\text { mafic volcanic rocks, bauxite and bauxite-bearing rocks } \\
\text { middle Afghanistan_Zuri and Kis). }\end{array}$ \\
\hline \multicolumn{4}{|c|}{ Carboniferous } \\
\hline $\mathrm{C}_{2} \mathrm{ls}$ & $\begin{array}{l}\text { Late Carboniferous } \\
\text { (Pennsylvanian) }\end{array}$ & $\begin{array}{l}\text { Stratified } \\
\text { sedimentary/mafic } \\
\text { volcanic }\end{array}$ & $\begin{array}{l}\text { Limestone, schist, sandstone, conglomerate, siltstone, mafic } \\
\text { volcanic rocks. }\end{array}$ \\
\hline $\mathrm{C}_{1 \mathrm{tv}} \mathrm{ls}$ & $\begin{array}{l}\text { Early Carboniferous, } \\
\text { Upper Tournaisian } \\
\text { Visean substage } \\
\end{array}$ & $\begin{array}{l}\text { Stratified } \\
\text { sedimentary }\end{array}$ & Limestone, shale, sandstone, mudstone, conglomerate. \\
\hline $\mathrm{C}_{1 \mathbf{t}} \mathrm{rl}$ & $\begin{array}{l}\text { Early Carboniferous, } \\
\text { Lower Tournaisian } \\
\text { substage }\end{array}$ & $\begin{array}{l}\text { Stratified } \\
\text { sedimentary/mafic } \\
\text { volcanic }\end{array}$ & Acid and mafic volcanic rocks, sandstone, shale, siltstone. \\
\hline \multicolumn{4}{|c|}{ PRECAMBRIAN } \\
\hline Ym & Mesoproterozoic & Metamorphic & Greenschist, gneiss, quartzite, marble, amphibolite. \\
\hline
\end{tabular}




\section{Metallogeny}

The Ahankashan AOI contains a copper (gold) skarn occurrence and a small number of minor polymetallic veins, hematite veins, a bedded barite occurrence, and the Khasan-Sansalaghei lead-zinc occurrence where the occurrence type is not yet classified (fig. 4). The copper (gold) skarn and the polymetallic veins are occurrence types that are commonly associated with porphyry copper deposits. The presence of these types within the AOI may indicate that permissive conditions for the occurrence of porphyry copper mineralization may once have been present in the AOI.

The Espesang vein hematite occurrence is thought to be related to Proterozoic iron mineralization associated with a Proterozoic gabbro-diorite stock (fig. 4; Montenat, 2009). Peters and others (2007) noted that other vein hematite occurrences in Afghanistan are present in Proterozoic, Permian, and Oligocene rocks and suggested that the Proterozoic-hosted iron occurrences may be products of contact metamorphism with Oligocene intrusive bodies.

The Taghab-Soni and the Taghab-Soni-I polymetallic vein occurrences date from the Triassic when a magmatic arc was possible along the southern coast of Eurasia (fig. 4). The veins occur from 5 to $10 \mathrm{~km}$ north of the Herat fault near the contact between Carboniferous sedimentary rocks (limestone, schist, sandstone, conglomerate, siltstone, and mafic volcanic rocks) and Late Triassic granodiorite, granophyre, and granite. The ASTER data indicate that the intrusive side of the contact has a large area of intense phyllic and argillic alteration (Mars, 2012). The intrusion, alteration, and mineralization are interpreted to coincide with the closing of the Paleo-Tethys Ocean by subduction of the ocean floor and suturing of a Cimmerian micro-continent to southern Eurasia (Montenat, 2009). Such a tectonic environment would be permissive for the development of porphyry copper deposits and related deposit types.

The Kushkak bedded barite occurrence is hosted in Late Cretaceous limestones and dolostones (fig. 4; Orris, 1986). The barite may have been deposited in an epicratonic marine basin or embayment after the closing of the Paleo-Tethys Ocean (Peters and others, 2007). Many of the barite deposits and occurrences in Afghanistan, however, are cross-cutting vein-type occurrences (Mossotti, 2011). The Kushkak occurrence is near the suture between the Hindu Kush Domain and the Afghan Turkestan Domain to the north (Montenat, 2009). The spatial association of bedded barite occurrences with the Herat fault and with lead-zinc occurrences in the central part of the country suggests that many of the barite occurrences are epigenetic and post-date the stratigraphic sequences in which they are hosted (Peters and others, 2007). The known association of bedded barite occurrences in other parts of the world with sedimentary exhalative lead-zinc deposits may indicate that the area where the Kushkak occurrence occurs was permissive for those types of base-metal mineralization. Mars (2012) identified no phyllic and argillic hydrothermal alteration in ASTER data in the vicinity of the Kushkak bedded barite occurrence.

The Ahankashan copper (gold) skarn occurs where Miocene porphyritic granodiorite has intruded Early Triassic terrigenous sedimentary-volcanic rocks that consist of limestone, dolomite, marl, variegated sandstone, gravelstone, conglomerate, and felsic and mafic volcanic rocks and a variety of Late Cretaceous carbonate and clastic sedimentary rocks (fig. 4; Mossotti, 2011). Skarn mineralization occurs near the contact between the intrusion and the stratified rocks. By using ASTER data, Mars (2012) showed sparse phyllic and argillic hydrothermal alteration in the vicinity of the mineralization and the intrusion. The intrusive rocks, in which the Ahankashan copper (gold) skarn occurs, appear to be part of a Miocene magmatic arc that generated a number of intrusions, both exposed and buried, that may be permissive for porphyry copper or related deposit types (Ludington and others 2007).

The Bedan polymetallic vein occurrence of undetermined age is hosted in Early Carboniferous (Tournaisian) felsic and mafic volcanic rocks with sandstone, shale, and siltstone (fig. 4; Fernette and 
Renaud, 2011). It is located a short distance north of the Herat fault and about $5 \mathrm{~km}$ west of a Late Triassic granodiorite, granophyre, and granite intrusion that Mars (2012) identified as having significant phyllic hydrothermal alteration. Additional carbonate minerals and epidote-chlorite alteration were identified in the vicinity of the Bedan polymetallic vein occurrence (Mars, 2012).

\section{Structural Geology}

The structural geology of the Ahankshan AOI was interpreted by the authors based on published and unpublished geologic maps that show the relations of thrust faults and strike-slip faults and the positions of granitic intrusions relative to the faults (Shcherbina and others, 1974a). It is clear from these structural relations that thrust faulting was followed by strike-slip faulting, which was followed by magmatic intrusions in a cycle. There are at least two of these cycles: one that culminates with intrusions in the Triassic and a second that culminates with intrusions in the Miocene. In assessing the potential for mineralization in the Ahankashan AOI, the latter cycle of thrusting, strike-slip faulting, and Miocene intrusions (based on only a few dates of mineralization) appears to be the most prospective type of mineral occurrence for the AOI.

In figure 5, the locations of the surface traces of a suite of thrust faults in the Ahankashan AOI are shown. Although the Geologic and Mineral Resource Map of Afghanistan does not identify them as thrust faults, from their arcuate form and associated rock, the authors interpret them to be a swarm of closely related mostly en echelon faults that are the product of thrusting (fig. 6; Doebrich and Wahl, 2006). In figure 6, Triassic, Cretaceous, Paleocene, and Eocene sedimentary rocks are shown along with the thrust faults. In figure 7, the next phase of deformation (right-lateral strike-slip faulting) is added to the elements of the previous figure, and in figure 8, the locations of the Miocene granitic intrusions have been added to complete the series. Figure 9 is a schematic cross section along $34^{\circ} 30^{\prime} \mathrm{N}$ latitude that shows the internal structure from $A$ to $A^{\prime}$ across the AOI. 


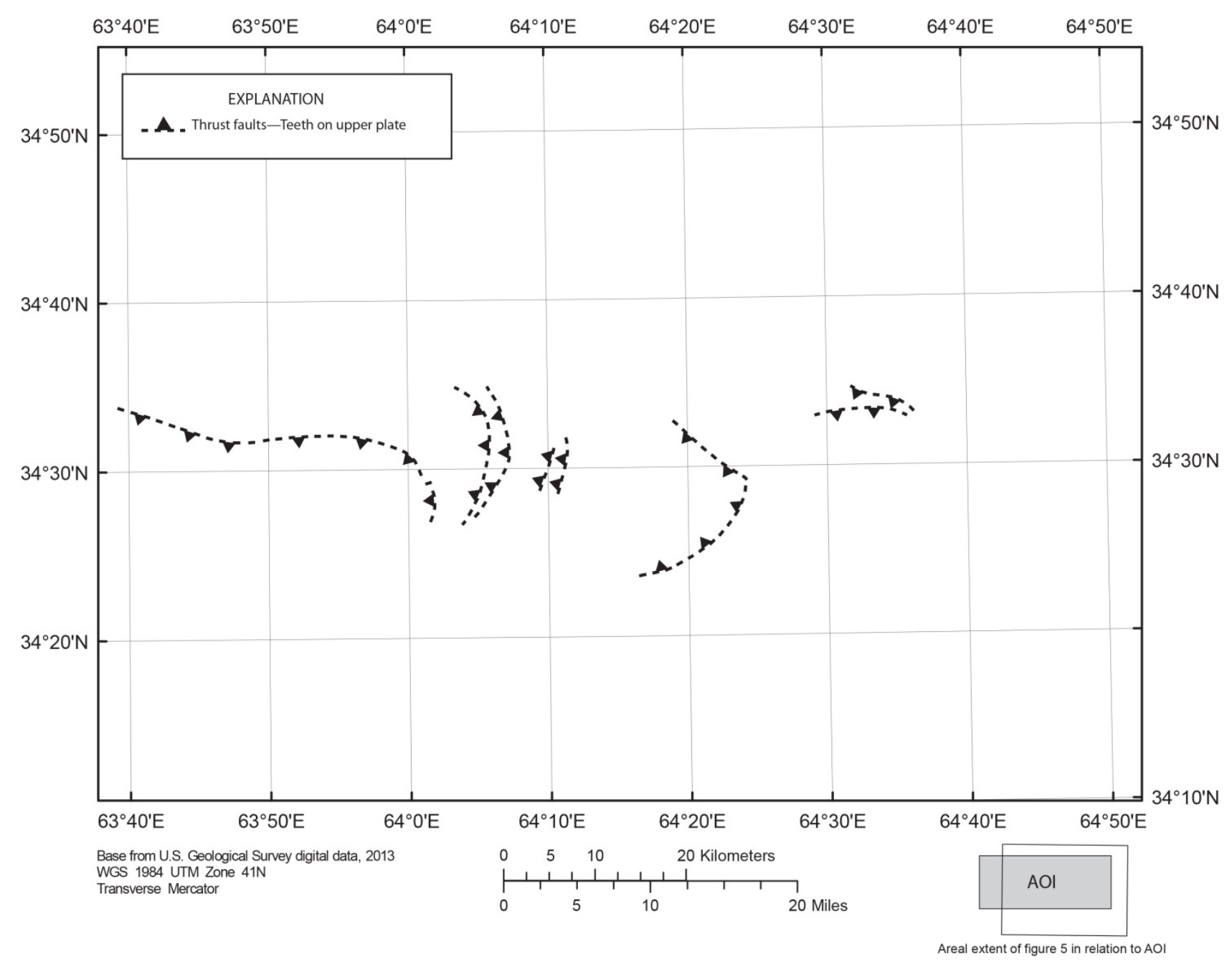

Figure 5. Thrust faults that are associated with Miocene granitic intrusions (not shown) in the Ahankashan Area of Interest (AOI) (Chmyriov and Mirzad, 1972; Doebrich and Wahl, 2006). 


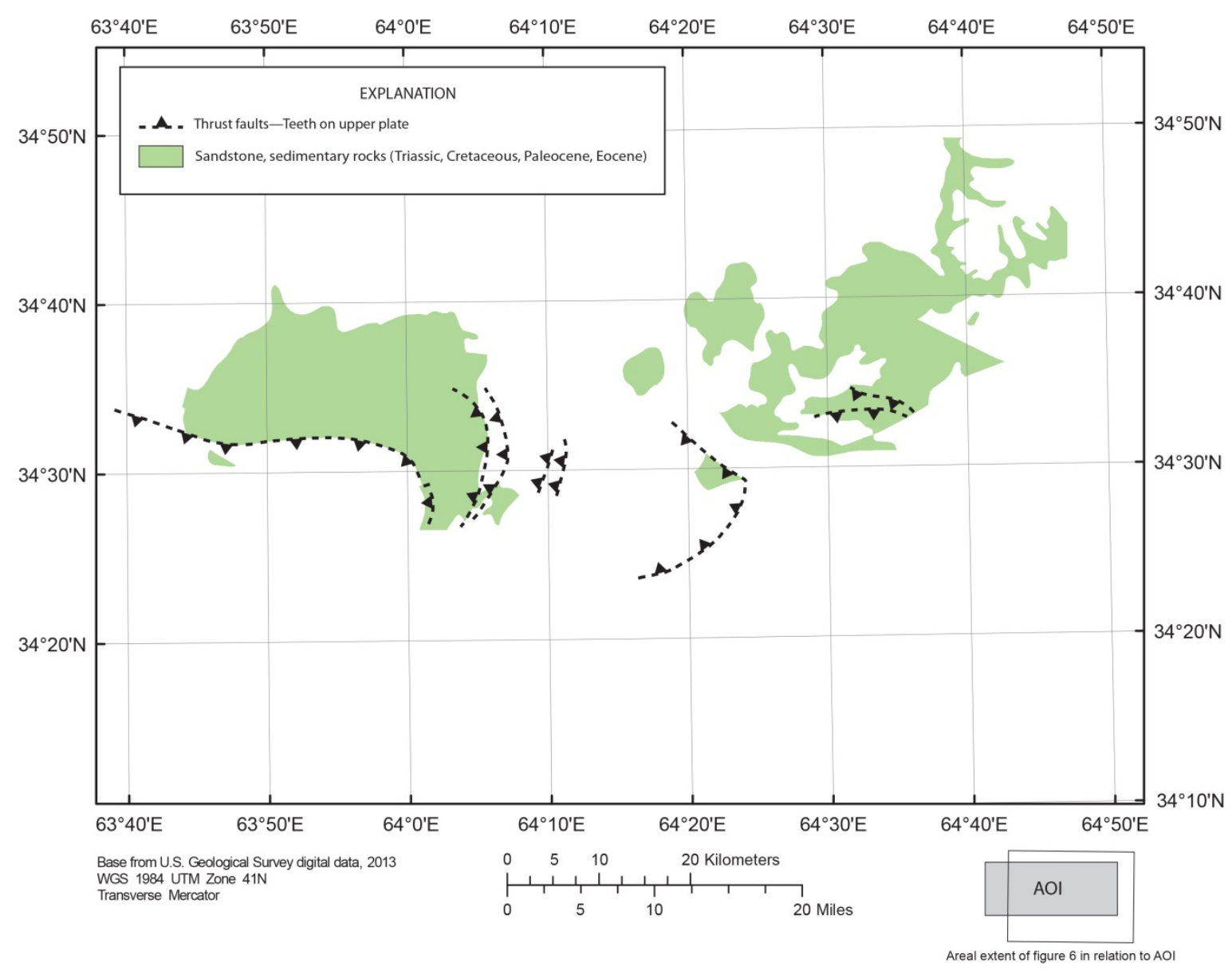

Figure 6. Triassic, Cretaceous, Paleocene, and Eocene sedimentary rocks and thrust fault traces that are associated with Miocene granitic intrusions (not shown) in the Ahankashan Area of Interest (AOI) (Chmyriov and Mirzad, 1972; Doebrich and Wahl, 2006). Thrust faults are interpreted from mapped contact relationships. 


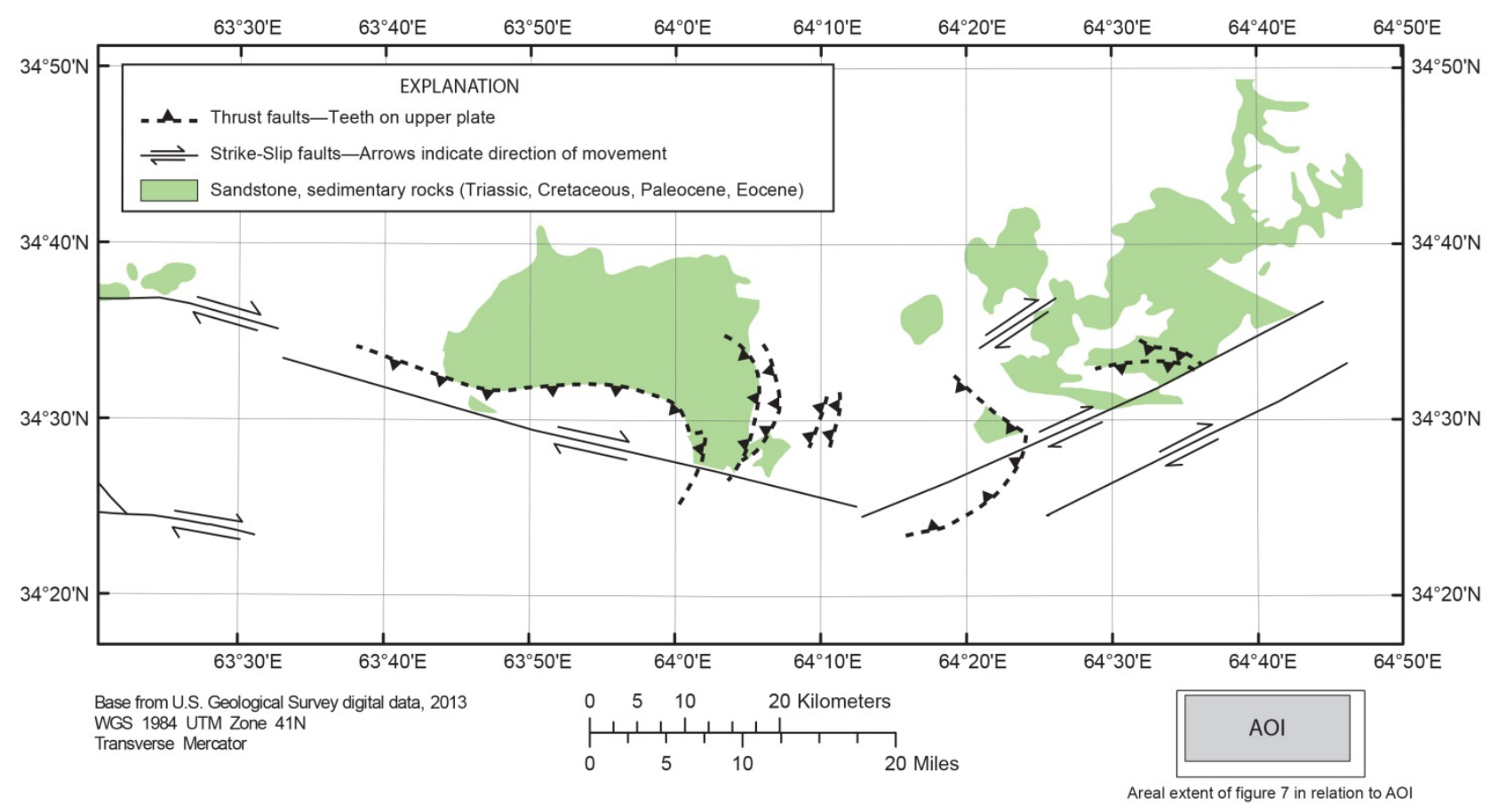

Figure 7. Right-lateral strike-slip faults; Triassic, Cretaceous, Paleocene, and Eocene sedimentary rocks; and thrust faults that are associated with Miocene granitic intrusions (not shown) in the Ahankashan Area of Interest (AOI) (Chmyriov and Mirzad, 1972; Doebrich and Wahl, 2006). Thrust faults are interpreted from mapped contact relationships. 


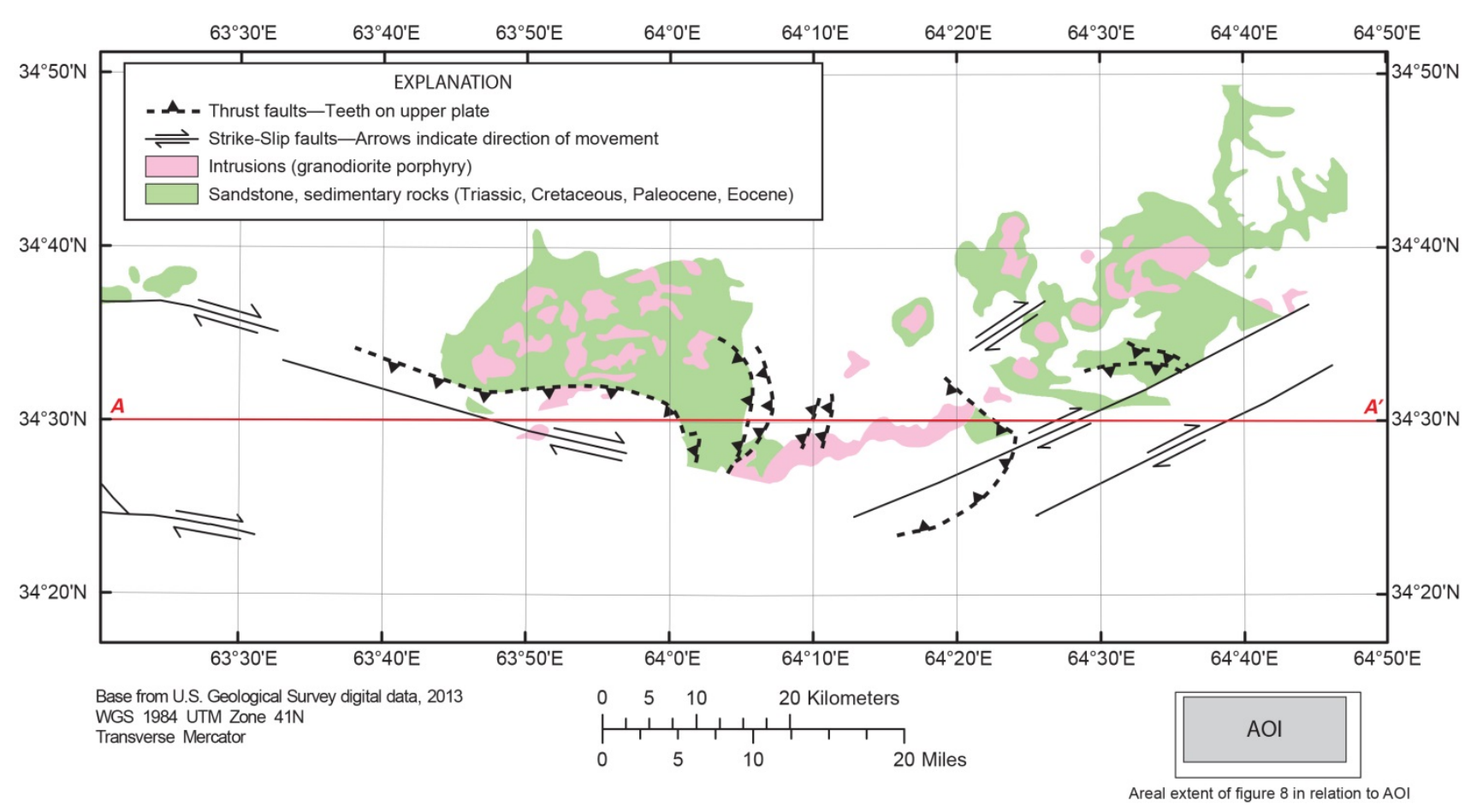

Figure 8. Miocene granitic intrusions; right-lateral strike-slip faults; Triassic, Cretaceous, Paleocene, and Eocene sedimentary rocks; and thrust fault traces associated with Miocene granitic intrusions in the Ahankashan Area of Interest (AOI) (Chmyriov and Mirzad, 1972; Doebrich and Wahl, 2006). These were the major elements used to analyze the structural geology of the area of interest. Line $A-A^{\prime}$ is the location for the cross section shown in figure 9.

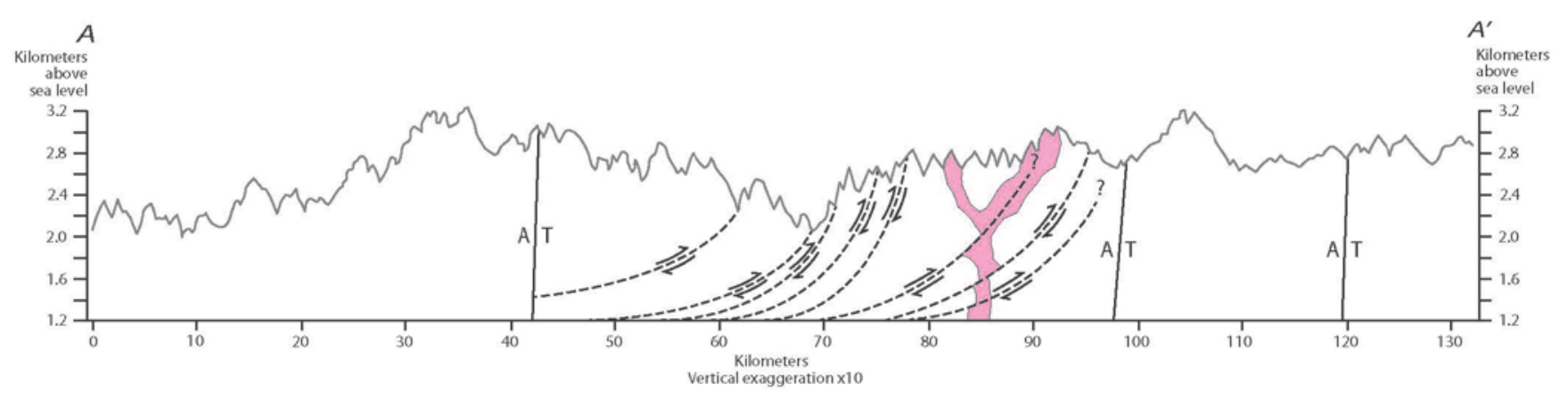

Figure 9. The Ahankashan Area of Interest along line $A-A^{\prime}$ from figure 8 showing the topographic profile in kilometers, Miocene thrust faults, strike-slip faults, and a Miocene granodioritic intrusion (Doebrich and Wahl, 2006). Subsurface parts of the intrusion (in red) are hypothetical and interpreted thrust faults are shown.

During the Miocene, collisional tectonism activated right-lateral right-stepping strike-slip faulting, which was the causal geologic factor that focused the emplacement of the granodiorite porphyry intrusions (figs. 7, 8). Note that near the center of the AOI, several of the intrusions are equant in shape, whereas others have complex lobate shapes (fig. 8). This variety in intrusive outline may be related to the complex mechanics internal to a set of thrust sheets. As the sheets were thrust one upon another, the rocks were fractured and thus prepared to receive the upwelling granitic magma that had been generated and focused by the strike-slip fault system. In a complex area of thrust and strike-slip 
faults, the magma found scattered areas of low dynamic pressure in which to intrude. In the eastern half of the AOI, several of the intrusions are nearly circular, suggesting emplacement of granitic intrusions in strike-slip fault duplexes. It is not uncommon for porphyry copper occurrences to be associated with the apical sections of such granitoid intrusions. High- and low-sulfide quartz veins are commonly distributed laterally, and also much alteration (phyllic and/or argillic) is associated with the porphyry mineralization (Drew, 2005). In addition to the intrusions shown, in several areas of the AOI, the sedimentary rocks are domed, which suggests that an unexposed intrusion has yet to be uncovered by erosion. These domed and intrusive rocks also may host porphyry copper occurrences. The cross section in figure 9 shows thrust and strike-slip faulting and emplacement of a Miocene granodioritic intrusion based on the geologic map of Doebrich and Wahl (2006). The thrusts in the cross section occurred one after the other as the thrust sheets were pushed over younger rocks until they ruptured and the next thrust sheet was pushed over the previous one. In this manner, the suite of en echelon thrust faults and thrust sheets seen in the southern part of the AOI were formed. The granodiorite intrusion, to some extent, follows zones of weakness created by the thrust faults. Subsequent strike-slip faulting determined where the intrusion was emplaced.

\section{Known Mineral Occurrences}

Seven mineral occurrences are reported to be present in the entirety of the Ahankashan AOI (table 2). No resource estimates, however, are available for any of the occurrences. These occurrences have been described in limited detail by Shcherbina and others (1974a,b) and Abdullah and others (1977). Later descriptions generally repeat the earlier information (Bowersox and Chamberlin, 1995; Orris and Bliss, 2002; Ludington and others, 2007; Peters and others, 2007).

Table 2. Selected characteristics of the known nonfuel mineral occurrences of the Ahankashan Area of Interest (Abdullah and others, 1977; Orris and Bliss, 2002).

\begin{tabular}{|c|c|c|c|c|}
\hline Name & Coordinates & Province & Type & Sample grades \\
\hline Bedan & 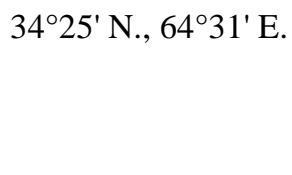 & Ghor & Polymetallic vein & $\begin{array}{l}\text { More than } 1 \text { percent copper, up to } \\
0.7 \text { percent lead, up to } 0.1 \text { percent } \\
\text { zinc and minor molybdenum, silver, } \\
\text { and gold. }\end{array}$ \\
\hline Espesang & 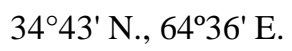 & Ghor & Hematite vein & No sample grades available. \\
\hline Hasan-Sansalagay & $\begin{array}{l}34^{\circ} 26^{\prime} 30^{\prime \prime} \text { N., } \\
63^{\circ} 42^{\prime} 30^{\prime \prime} \mathrm{E} .\end{array}$ & Ghor & Polymetallic vein? & $\begin{array}{l}\text { Up to } 4.9 \text { percent lead, up to } 1 \text { percent } \\
\text { zinc, } 0.9 \text { percent copper, and } \\
0.02 \text { percent antimony. }\end{array}$ \\
\hline
\end{tabular}


Table 2. Selected characteristics of the known nonfuel mineral occurrences of the Ahankashan Area of Interest (Abdullah and others, 1977; Orris and Bliss, 2002).-Continued

\begin{tabular}{|c|c|c|c|c|}
\hline Name & Coordinates & Province & Type & Sample grades \\
\hline Taghab-Soni & $34^{\circ} 26^{\prime}$ N., 634ㅇ' E. & Herat & Polymetallic vein & $\begin{array}{l}0.08 \text { to } 3.08 \text { percent copper, up to } \\
1.0 \text { percent lead, } 0.01 \text { to } 0.1 \text { percent } \\
\text { zinc, and } 0.03 \text { to } 3 \text { gram of gold per } \\
\text { ton. }\end{array}$ \\
\hline Taghab-Soni-I & $34^{\circ} 26^{\prime}$ N., $63^{\circ} 48^{\prime}$ E. & Herat & Polymetallic vein & $\begin{array}{l}0.5 \text { to } 3.0 \text { percent copper, } 0.3 \text { to } \\
1 \text { percent lead, and } 0.01 \text { to } \\
0.07 \text { percent tin. }\end{array}$ \\
\hline
\end{tabular}

\section{Ahankashan Copper (Gold) Skarn}

In the AOI, the known mineral occurrence with the greatest mineral potential is the Ahankashan copper (gold) skarn in Badghis Province. At this site, copper and gold mineralization has been noted in zones of hydrothermally altered rocks (skarns) related to an intrusion of Miocene granite porphyry invading terrigenous and terrigenous-carbonate rocks of Early Triassic and Late Cretaceous age (Ludington and others, 2007). The copper mineralization occurs in magnetite-hematite and epidotegarnet-magnetite skarns, from 10 to $15 \mathrm{~m}$ in thickness and covers about 20,000 square meters $\left(\mathrm{m}^{2}\right)$. It occurs as nests, veinlets, and finely disseminated grains (Shcherbina and others, 1974a,b; Ludington and others, 2007; Peters and others, 2007). The ore minerals include chalcopyrite, covellite, chalcocite, cuprite, malachite, and azurite. The metal contents are 0.01 to 0.1 percent copper, 0.2 to 0.5 gram of gold per ton [up to 32.3 grams per ton (g/t) in several samples], up to 0.4 percent combined lead and zinc, and 0.05 percent molybdenum (Shcherbina and others, 1974a,b; Ludington and others, 2007; Peters and others, 2007). Hydrothermal mineralization of the veinlet-dissemination type is developed in the altered granite porphyry, which is localized in highly tectonized zones and in segments penetrated by numerous quartz stringers, as well as in shattered, pyritized, kaolinized, and limonitized rocks (the mineralized area is $1.5 \mathrm{~km}^{2}$ ) (Shcherbina and others, 1974a,b; Ludington and others, 2007; Peters and others, 2007). They occur as six closely spaced subparallel mineralized zones from 11 to 75 meters (m) wide, more rarely up to $150 \mathrm{~m}$ wide and run 0.7 to $2.5 \mathrm{~km}$ long (Shcherbina and others, 1974a,b; Ludington and others, 2007; Peters and others, 2007). The following metal contents have been determined: 0.1 to 0.5 percent (3.60 percent at maximum) copper, 1 to 1.3 grams of gold per ton (8 grams of gold per ton at maximum), up to 0.05 percent lead, up to 0.4 percent zinc, and up to 0.07 percent molybdenum (Shcherbina and others, 1974a,b; Ludington and others, 2007; Peters and others, 2007).

\section{Bedan Polymetallic Veins}

The Bedan occurrence in Ghor Province represents a series of quartz and barite-quartz veins and muscovite pegmatite dikes with disseminated sulfides (fig. 4). The country rock is Proterozoic schist. The metal contents are more than 1 percent copper, up to 0.7 percent lead, up to 0.1 percent zinc, and minor molybdenum, silver, and gold (Dronov and others, 1972; Abdullah and others, 1977; Ludington and others, 2007; Peters and others, 2007).

\section{Espesang Iron-Base-Metal Occurrence}

The Espesang vein hematite occurrence is reported to have Proterozoic iron mineralization associated with a Proterozoic gabbro-diorite stock (fig. 4). Significant minerals include galena, sphalerite, pyrite, chalcopyrite, and chalcocite. Mineralization is in a 3,000-m-long and 50-m-thick fault 
zone with strong iron mineralization (Abdullah and others, 1977; Bowersox and Chamberlin, 1995; Orris and Bliss, 2002).

\section{Khasan-Sansalagay Shear-Zone Occurrence}

As described by Dronow and others (1972), the Hasan-Sansalagay occurrence in Ghor Province is located in a 2.0-m-wide and 150-m-long shattered and mineralized shear zone that has been distinguished in Lower-Middle Jurassic limestone and sandstone (fig. 4). Metal contents are as follows: up to 4.9 percent lead, up to 1 percent zinc, 0.9 percent copper, and 0.02 percent antimony (Dronov and others, 1972; Abdullah and others, 1977; Bowersox and Chamberlin, 1995; Orris and Bliss, 2002).

\section{Kushkak Vein Occurrence}

The Kushkak vein occurrence in Ghor Province is a 60-m-wide and 120-m-long mineralized stock, which comprises barite, quartz, and calcite with irregularly disseminated lead and copper sulfides found in Late Cretaceous limestone (fig. 4). The following metal contents have been determined: 4.05 to 6.3 percent copper, 1.2 to 1.5 percent lead, 0.07 to 0.5 percent zinc, 0.6 to 1.1 grams of gold per ton, and 52.24 percent barite (Dronov and others, 1972; Abdullah and others, 1977; Bowersox and Chamberlin, 1995; Orris and Bliss, 2002; Ludington and others, 2007; Peters and others, 2007). The Kushkak occurrence is near the suture between the Hindu Kush and the Afghan Turkestan Domains

(Montenat, 2009).

\section{Taghab-Soni Polymetallic Veins}

In the southwestern quadrant of the Ahankashan AOI, the Taghab-Soni polymetallic vein occurrence lies along the contact between an early Carboniferous granodiorite and lower Carboniferous sedimentary rocks and consists of two main occurrences located about $10 \mathrm{~km}$ apart (fig. 4). The Taghabi-Soni occurrence contains more than 40 veins between 40 and 1,000 m long and from 0.4 to $15 \mathrm{~m}$ wide, 11 of which contain from 0.08 to 3.08 weight percent copper and from 0.3 to 3 grams of gold per ton with accessory lead and zinc (Abdullah and others, 1977; Bowersox and Chamberlin, 1995; Orris and Bliss, 2002; Ludington and others, 2007; Peters and others, 2007).

\section{Taghab-Soni-I Polymetallic Veins}

The Taghab-Soni-I polymetallic vein occurrence, which is located about $10 \mathrm{~km}$ east of the Taghab-Soni occurrence, is in a zone that is 3,000 m long and $900 \mathrm{~m}$ wide (fig. 4). The Taghab-Soni-I zone consists of several quartz sulfide veins and veinlets between 0.1 and $10 \mathrm{~m}$ wide, up to 1,200 m long, containing 0.5 to 3 weight percent copper with lesser amounts of lead and tin (Dronov and others, 1972; Abdullah and others, 1977; Bowersox and Chamberlin, 1995; Orris and Bliss, 2002; Ludington and others, 2007; Peters and others, 2007). Stream sediments in this part of the Ahankashan AOI are anomalously rich in gold (Peters and others, 2007).

\section{Ahankashan Study Area}

The Ahankashan study area may be the most promising of the four study areas of the AOI selected for closer analysis. It includes the Ahankashan copper (gold) skarn and related Miocene granitic intrusions $\left(\mathbf{N}_{\mathbf{1}} \mathbf{d i g}\right.$ ) in the northeastern part of the AOI (figs. 10, 11). The study area is entirely in the Band-e-Bayan Block/Central Pamirs Domain, which is north of the suture joining that domain with the Hindu Kush Domain. The Miocene intrusive rocks may host some porphyry-style mineralization. 
The intrusive rocks consist of diorite, granodiorite, monzonite, syenite, and nepheline syenite porphyry (Doebrich and Wahl, 2006; Ludington and others, 2007). These rocks, however, have no apparent magnetic signature and may be ilmenite-series rocks and thus may not be optimal for the formation of porphyry copper mineralization (Ludington and others, 2007).

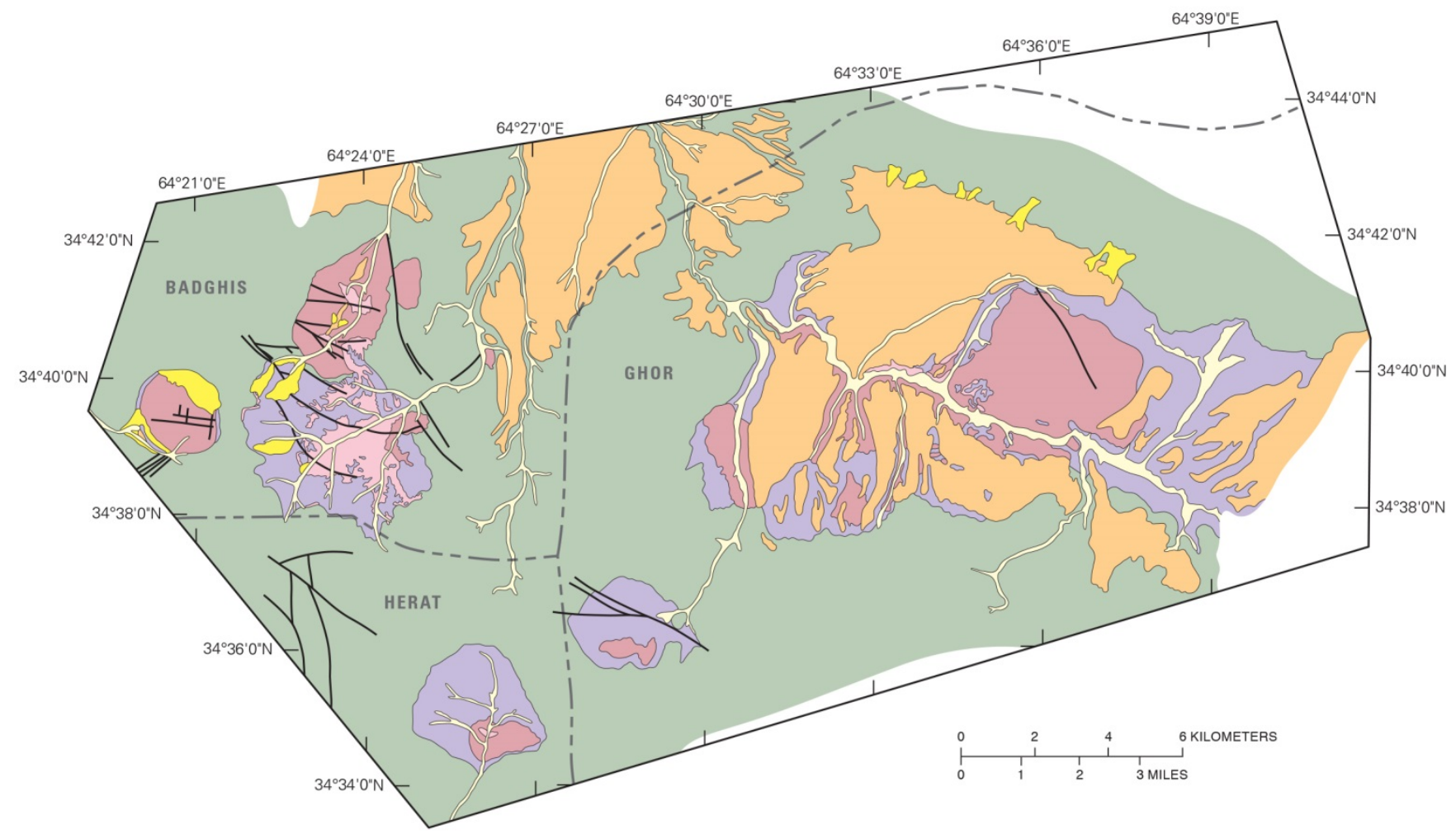

STRATIFIED ROCKS
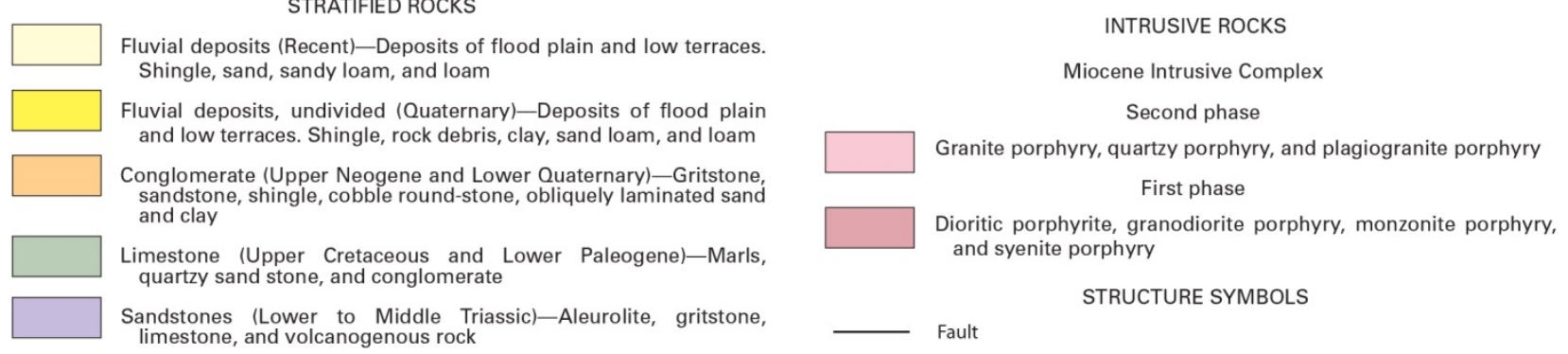

Figure 10. Diorite intrusives in the Ahankashan copper (gold) skarn study area (Shcherbina and others, 1974a,b). Geologic units of Shcherbina and others (1974a,b) roughly correlate to those of Doebrich and Wahl (2006). 


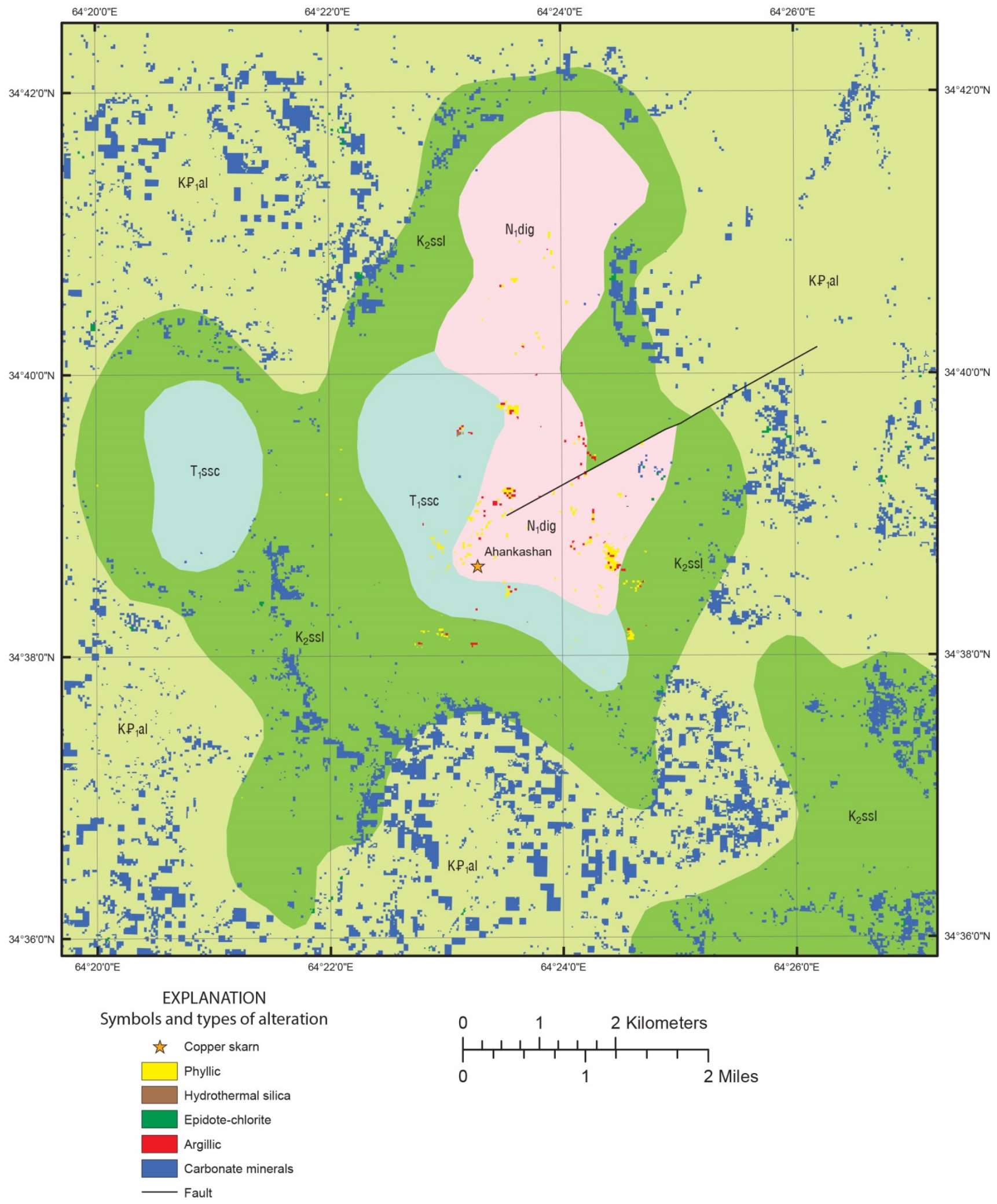

Figure 11. Hydrothermal alteration zones, location of the diorite intrusive, the skarn, and the surrounding area of the Ahankashan copper (gold) skarn study area (Doebrich and Wahl, 2006; Mars, 2012). Explanations of rock units are given in table 1 and colors are given on figure 3 . 
Figure 11 shows that the dioritic rocks $\left(\mathbf{N}_{\mathbf{1}} \mathbf{d i g}\right)$ and adjacent sedimentary rocks $\left(\mathbf{K}_{\mathbf{2}} \mathbf{s s l}\right)$ in the study area are faulted and offset. As the intrusion was emplaced, the sedimentary rocks

( $\mathbf{T}_{\mathbf{1}} \mathbf{s s c}$ and $\mathbf{K}_{\mathbf{2}} \mathbf{s s l}$ ) became domed. Subsequent erosion exposed the sedimentary rocks and locally the intrusive rocks. The intrusion that hosts the skarn has been exposed by erosion, whereas the domed $\mathbf{T}_{\mathbf{1}}$ ssc rocks in the western part of the study area cover an assumed dioritic $\left(\mathbf{N}_{\mathbf{1}} \mathbf{d i g}\right)$ intrusion that has not been exposed by erosion.

The intrusion that hosts the Ahankashan copper (gold) skarn has sparse phyllic and argillic alteration, and no significant carbonate mineralization is recognized in the ASTER data (Mars, 2012). At the skarn occurrence, hydrothermal mineralization of the veinlet-dissemination type also is developed in the altered granite porphyry (Mars, 2012). Mineralization is localized in highly tectonized zones and in segments penetrated by numerous quartz stringers, as well as in shattered, pyritized, kaolinized, and limonitized rocks; the mineralized area is $1.5 \mathrm{~km}^{2}$ (Abdullah and others, 1977).

\section{Syahsang-Kushkak Study Area}

This study area is located in Badghis and Herat Provinces in the eastern part of the AOI, which is north of the Herat fault and lies mostly in the Hindu Kush Domain but with the northern quarter in the Afghan Turkestan Domain (figs. 2, 12). It was delineated to include the northeast-southwest-trending string of Miocene granitic intrusions ( $\mathbf{N}_{\mathbf{1}} \mathbf{d i g}$ ) and several areas where Mars (2012) recognized pervasive to scattered phyllic and argillic alteration in the ASTER images. Many of the altered areas coincide with or are proximal to the Miocene intrusions (fig. 12). Alteration in and around the intrusions is less intensive with distance from the Herat fault (Mars, 2012). Those intrusions in the southern part of the study area appear to have more alteration than do those in the northern part of the study area; some areas in the southeastern part of the study area are intensely altered, but have no corresponding exposed intrusion. The Kushkak barite occurrence is the only reported mineral concentration in the study area. No phyllic or argillic alteration has been identified in the vicinity of this occurrence (Mars, 2012). 


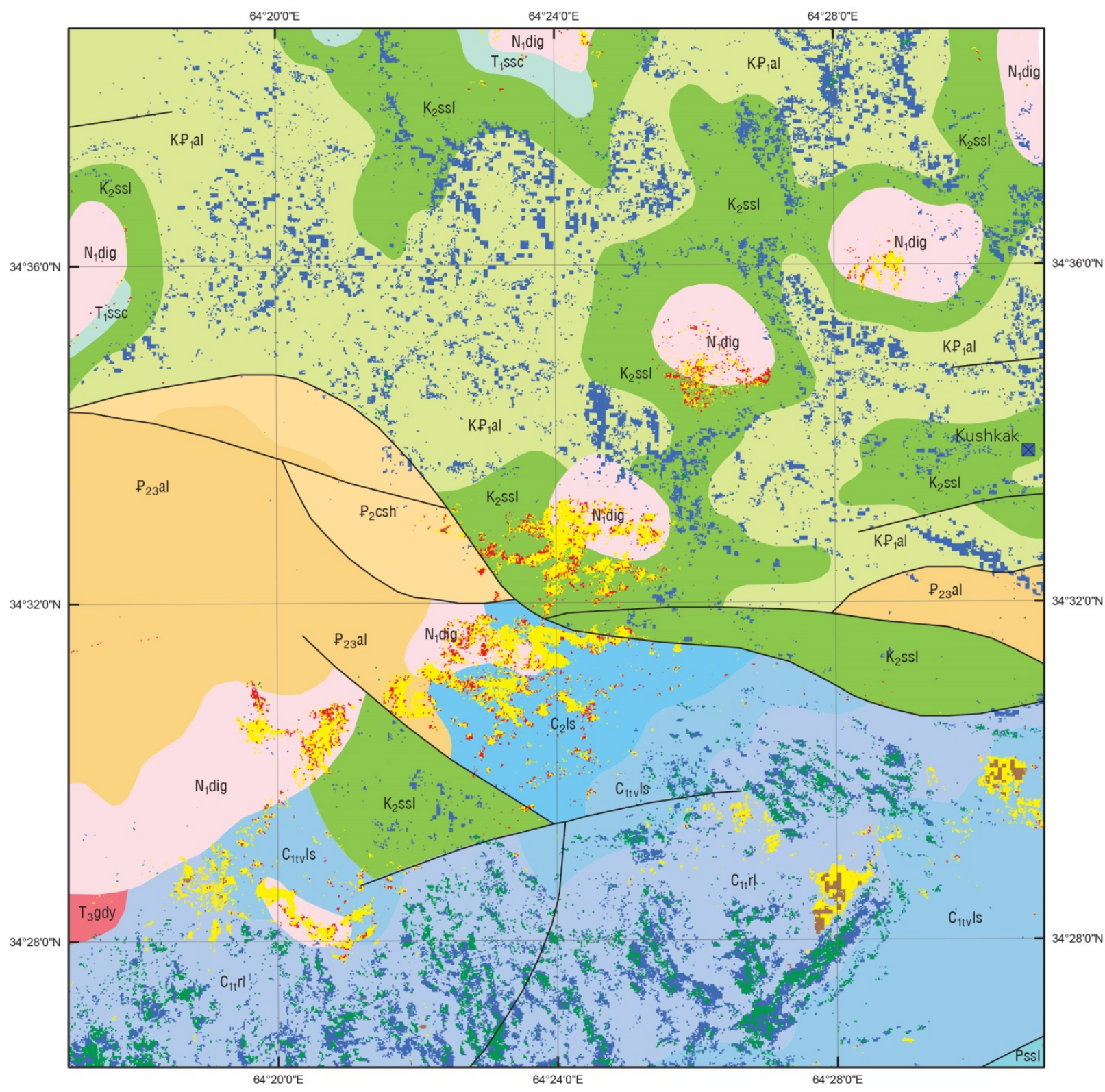

EXPLANATION

Symbols and types of alteration
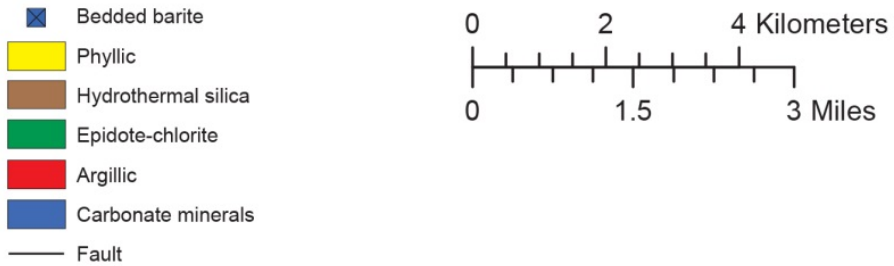

Figure 12. Hydrothermal alteration zones and the location of the Miocene intrusions in the Syahsang-Kushkak subarea of the Ahankashan Area of Interest (Shcherbina and others, 1974a,b; Mars, 2012). Explanations of rock units are given in table 1 and colors are given on figure 3 (Doebrich and Wahl, 2006). 


\section{Taghab-Soni Study Area}

The Taghab-Soni study area is located along the southern boundary of the AOI in Herat Province (fig. 2). The Herat fault trends east to west across the southern part of the AOI. As a result, the southern one-quarter of the study area is in the Band-e-Bayan Block/Central Pamirs Domain and the northern three-quarters are in the Hindu Kush Domain. This area is prospective for the occurrence of porphyry copper and related polymetallic mineralization (Ludington and others, 2007; Peters and others, 2007). It includes the Taghab-Soni and the Taghab-Soni-I polymetallic vein occurrences and a large field of phyllic hydrothermal alteration (figs. 2, 13; Mars, 2012). The alteration occurs within the intrusion margin near the contact between carbonate $\left(\mathbf{C}_{2} \mathbf{l s}\right)$ and clastic sedimentary rocks with minor mafic volcanic rocks and the granodiorite, granosyenite, granophyre, and granite intrusion ( $\left.\mathbf{T}_{3} \mathbf{g d y}\right)$. The Taghab-Soni polymetallic vein occurrence is located on the northern edge of the phyllic-alteration field in the contact between $\mathbf{T}_{3}$ gdy and $\mathbf{C}_{2}$ ls (fig. 13). A relatively narrow band of carbonate minerals and epidote-chlorite alteration is seen to the south of the wide field of phyllic hydrothermal alteration. The presence of the intermediate intrusive rocks and the pervasive phyllic hydrothermal alteration are indicators of potential for porphyry copper and related polymetallic occurrences (Ludington and others, 2007; Peters and others, 2007).

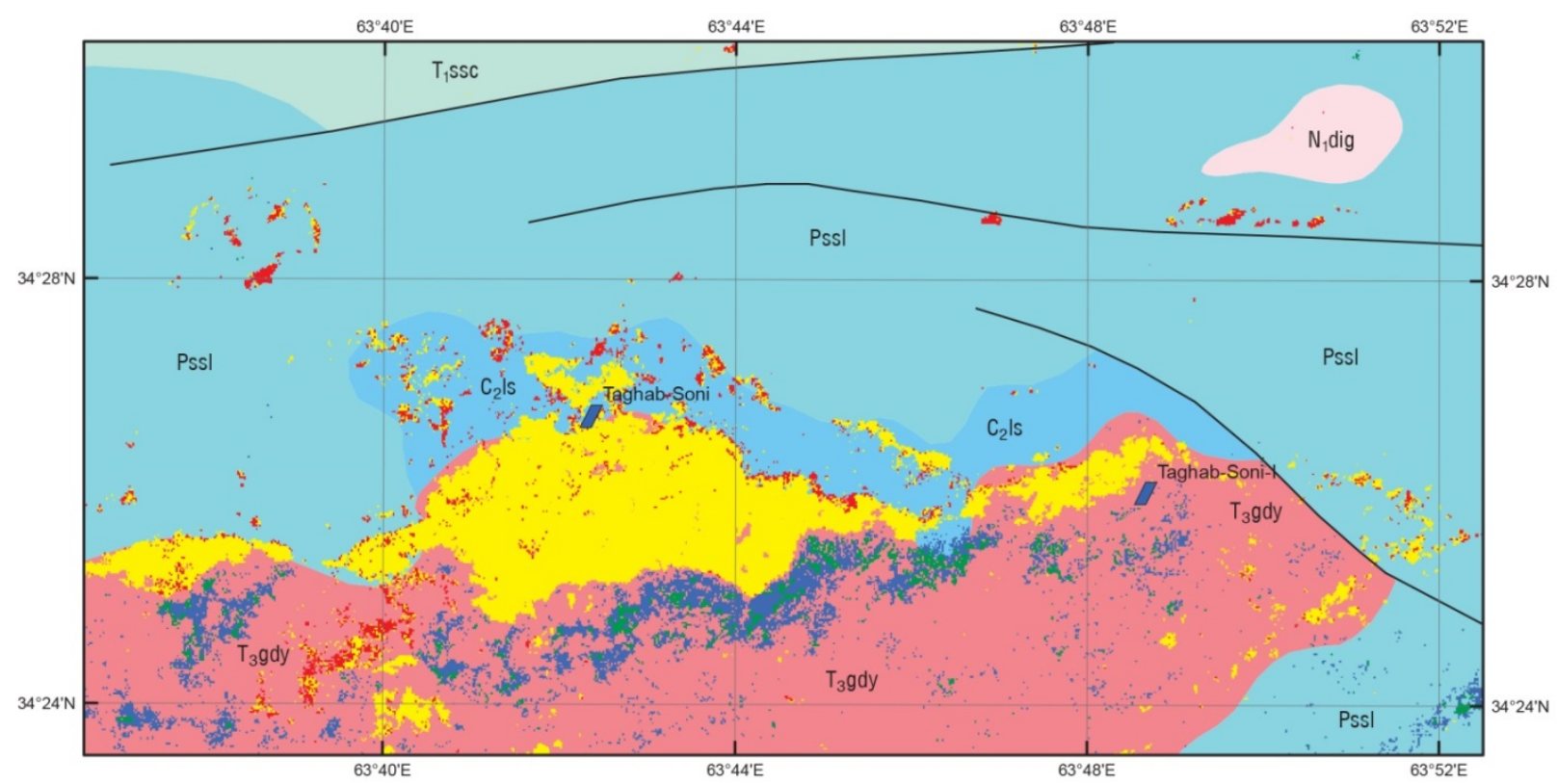

EXPLANATION Symbols and types of alteration
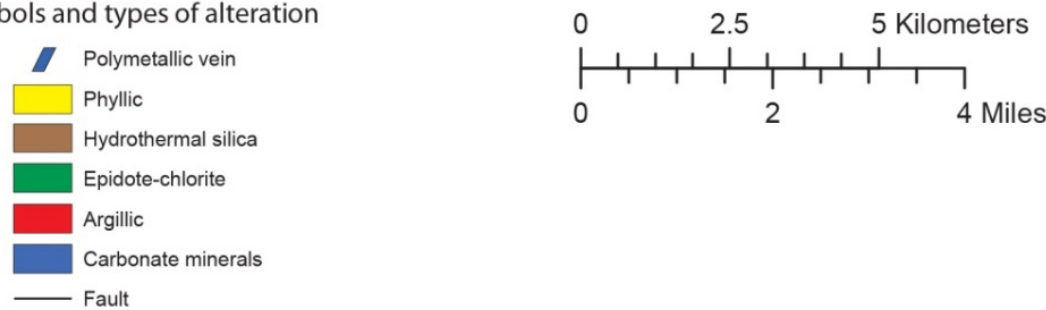

Figure 13. Hydrothermal alteration zones and geology in the Taghab-Soni subarea of the Ahankashan Area of Interest (Shcherbina and others, 1974a,b; Mars, 2012). Explanations of rock units are given in table 1 and colors are given on figure 3 (Doebrich and Wahl, 2006). 


\section{Zakak-e ‘Olya Study Area}

This study area is remote and sparsely explored and has no reported mineral occurrences (fig. 14). The southern boundary of the study area is slightly north of and parallel to the Herat fault, but the great majority of the study area is in the Hindu Kush Domain with only a fraction in the northeastern corner of the Afghan Turkestan Domain.

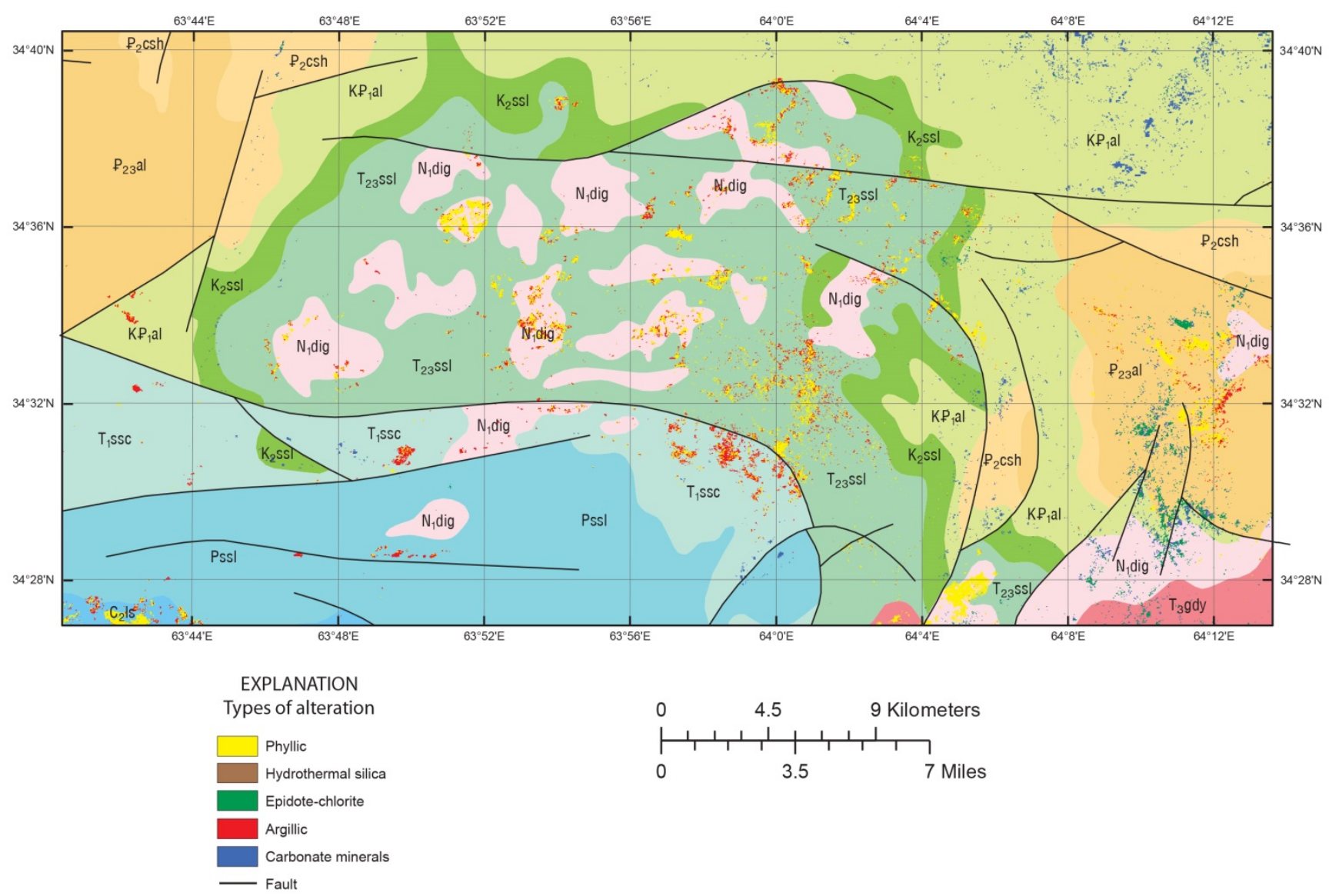

Figure 14. Hydrothermal alteration zones and geology of the Zakak-e 'Olya subarea of the Ahankashan Area of Interest (Mars, 2012). Explanations of rock units are given in table 1 and colors are given on figure 3 (Doebrich and Wahl, 2006).

The potential for mineralization of the Zakak-e 'Olya area, however, has been noticed previously. Ludington and others (2007) recognized the rocks of this area as having potential for porphyry copper mineralization and included the area in their Feroz Koh tract. In addition, this area was once included in the Shere-Arman area by Peters and others (2007), which is a region that was recognized as permissive for natural microcrystalline graphite because of the intrusion of Middle to Late Triassic ( $\left.\mathbf{T}_{23} \mathbf{s s l}\right)$ and Miocene $\left(\mathbf{N}_{\mathbf{1}} \mathbf{d i g}\right)$ granitic rocks into Lower Carboniferous $\left(\mathbf{K}_{\mathbf{2}} \mathbf{s s} \mathbf{l}\right)$ sedimentary rocks and coal beds that may have graphitized the coal and other organic material.

The Zakak-e 'Olya study area is chosen here for its potential for porphyry copper and related metallic occurrences because those same dioritic intrusions $\left(\mathbf{N}_{\mathbf{1}} \mathbf{d i g}\right)$ emplaced into sedimentary rocks $\left(\mathbf{T}_{23}\right.$ ssl and $\mathbf{K}_{2}$ ssl) are adjacent to areas having reported phyllic and argillic hydrothermal alteration, which suggests that hydrothermal fluids had changed the chemical character of the intrusions and the country rocks (Mars, 2012). 


\section{Placer Gold}

Gold placer occurrences are not reported for the Ahankashan AOI. Artisanal placer gold mining may have occurred in the past, along with other mining in the area of the Ahankashan copper (gold) skarn occurrence, but any evidence has long since disappeared. Much of the area around the Ahankashan occurrence contains anomalous gold in stream sediments as do the extreme western parts of the tract (Shcherbina and others, 1974a,b; Ludington and others, 2007; Peters and others, 2007). Stream sediments in the Taghab-Soni area of the AOI also are reported to be anomalously rich in gold, so it is possible that the potential for at least small-scale placer occurrences exists downstream from the reported skarn and polymetallic vein mineralization (Ludington, 2007). Placer occurrences also may be found in streambeds downstream from areas where Mars (2012) identified extensive hydrothermal alteration from the ASTER data; this suggests that the areas are prospective for porphyry copper and other polymetallic mineralization. Discovery of gold-bearing occurrences in the AOI would greatly increase the potential for gold placers.

\section{Summary of Potential}

The Ahankashan AOI is speculative for the presence of undiscovered mineral resources. It has very few prospects and has not been sufficiently explored and prospected by either obsolete or modern technologies (Ludington and others, 2007; Peters and others, 2007).

As of spring 2013, the USGS had not visited the area, and although it was included in a permissive porphyry copper tract, it was excluded from the 2007 assessment as an AOI because at that time, the location of the Ahankashan skarn occurrence was uncertain (Ludington and others, 2007; Peters and others, 2007). This AOI will require on-the-ground site visits, field mapping, and detailed sampling to authenticate and quantify remotely sensed indications of mineralization.

This report selected four subareas that may contain undiscovered mineral resources, and Mars (2012) identified numerous areas, both within and outside of the subareas, that appear to have enough hydrothermal alteration near Late Triassic and Miocene felsic intrusions to warrant on-the-ground investigations and possibly a modern scientific exploration program. On the one hand, the description of the Ahankashan copper (gold) skarn occurrence notes the presence of stockwork and veinlet mineralization, which characterizes many porphyry copper occurrences. On the other hand, only a few known polymetallic veins have been found in the tract. Normally, such veins and other types of mineral occurrences are found in large numbers near porphyry copper deposits as are large areas of extensive hydrothermal alteration. The erosion level in the region may not be deep enough to expose a porphyry environment and, thus, any occurrences may be hidden.

The original Feroz Koh tract (ppycu08) of Ludington and others (2007) had an area of $6,266 \mathrm{~km}^{2}$, whereas the new Ahankashan AOI has an area of 6,415 $\mathrm{km}^{2}$. The intersection of the Feroz Koh tract with the Ahankashan AOI is an area of 3,804 km², which is an almost 60-percent overlap. For the original 2007 Feroz Koh porphyry copper tract, Ludington and others (2007) estimated a 90-percent chance of 0 or more undiscovered porphyry copper occurrence in the larger tract, a 50-percent chance of 0 or more, and a 10-percent chance of 2 or more porphyry copper occurrences (Peters and others, 2007).

\section{References Cited}

Abdullah, Sh., Chmyriov, V.M., Stazhilo-Alekseev, K.F., Dronov, V.I., Gannan, P.J., Rossovskiy, L.N., Kafarskiy, A.Kh., and Malyarov, E.P., 1977, Mineral resources of Afghanistan (2d ed.): Kabul, Afghanistan, Republic of Afghanistan Geological and Mineral Survey, 419 p. 
Bowersox, G.W., and Chamberlin, B.E., 1995, Gemstones of Afghanistan: Tucson, Ariz., Geoscience Press, v. 32, 220 p.

Boyd, O.S., Mueller, C.S., and Rukstales, K.S., 2007, Preliminary earthquake hazard map of Afghanistan: U.S. Geological Survey Open-File Report 2007-1137, 29 p.

Chmyriov, V.M., and Mirzad, S.H., 1972, Geological map of Afghanistan: Ministry of Mines and Industries of Royal Afghanistan, Department of Geology and Mines, scale 1:1,000,000.

Debon, F., Afzali, H., Le Fort, P., Sonet, J., and Zimmermann, J.L., 1987, Plutonic rocks and associations in Afghanistan-Typology, age, and geodynamic setting: Mémoires Sciences de la Terre, no. 49, $132 \mathrm{p}$.

Doebrich, J.L., and Wahl, R.R., 2006, Geologic and mineral resource map of Afghanistan: U.S. Geological Survey Open-File Report 2006-1038, scale 1:850,000. Available online at http://pubs.usgs.gov/of/2006/1038/.

Doebrich, J.L., Ludington, S.D., Peters, S.G., Finn, C.A., Mars, J.C., Rowan, L.C., Stoeser, D.B., King, T.M., Eppinger, R.G., Wasy, A., and Younusi, M.O., 2007, Porphyry copper potential of Tethyan magmatic arcs of Afghanistan: Society for Geology Applied to Mineral Occurrences, 4 p.

Drew, L.J., 2005, A tectonic model for the spatial occurrence of porphyry copper and polymetallic vein occurrences-Applications to Central Europe: U.S. Geological Survey, Scientific Investigations Report 2005-5272, 36 p.

Dronov V.I., Kalimulin S.M., Sborshchikov I.M., Svezhentsov V.P., Chistyakov A.N., Zelensky E.D., and Cherepov, P.G., 1972, The geology and minerals of North Afghanistan: Kabul, Afghanistan, Department of Geological and Mineral Survey, parts of map sheets 400-II and 500-I, the Kaysar-Hari Rod Interfluve area.

Fernette, G., and Renaud, K., 2011, Summary of the Nalbandon Lead Zinc Area of Interest, chap. 11A of Peters, S.G., King, T.V.V., Mack, T.J., Chornack, M.P., eds., and the U.S. Geological Survey Afghanistan Mineral Assessment Team, 2011, Summaries of important areas for mineral investment and production opportunities of nonfuel minerals in Afghanistan: U.S. Geological Survey Open-File Report 2011-1204, v. 2, p.851-895. (Also available at http://pubs.usgs.gov/of/2011/1204/.)

John, D.A., Ayuso, R.A., Barton, M.D., Blakely, R.J., Bodnar, R.J., Dilles, J.H., Gray, Floyd, Graybeal, F.T., Mars, J.C., McPhee, D.K., Seal, R.R., Taylor, R.D., and Vikre, P.G., 2010, Porphyry copper deposit model, chap. B of Mineral deposit models for resource assessment: U.S. Geological Survey Scientific Investigations Report 2010-5070-B, 169 p.

Karapetov, S.S., Sonin, I.I., and Khain, V.E., 1975, Some fundamental particularities of the structure and evolution of the Pamiro-Afghan segment in the Eurasian alpine folded belt [in Russian]: Vestnik Moskova Universitat, 3, p. 38-46.

Ludington, S.D., Orris, G.J., Bolm, K.S., Peters, S.G., and the U.S. Geological Survey-Afghanistan Ministry of Mines and Industry Joint Mineral Resource Assessment Team, 2007, Preliminary mineral resource assessment of Afghanistan: U.S. Geological Survey Open-File Report 2007-1055, 47 p. Available online at http://pubs.usgs.gov/of/2007/1005/.

Mars, J.C., 2012, Mapping altered rocks in the Ahankashan area of Afghanistan using Advanced Spaceborne Thermal Emission and Reflection Radiometer (ASTER) data: U.S. Geological Survey unpublished administrative report. Available online at http://afghanistan.cr.usgs.gov/mineralspublications-maps.

Montenat, Christian, 2009, The Mesozoic of Afghanistan: Gulf PetroLink, Bahrain, GeoArabia, v. 14, no. 1, p. 147-210.

Mossotti, V.G., 2011, Introduction to industrial minerals, chap. 16A of Peters, S.G., King, T.V.V., Mack, T.J., Chornack, M.P., eds., and the U.S. Geological Survey Afghanistan Mineral Assessment 
Team, 2011, Summaries of important areas for mineral investment and production opportunities of nonfuel minerals in Afghanistan: U.S. Geological Survey Open-File Report 2011-1204, p. 1227-1242 plus appendixes on DVD. (Also available at http://pubs.usgs.gov/of/2011/1204/.)

Okaya, N., Onishi, C.T., and Mooney, W.D., 2009, Tethys and the evolution in Afghanistan-Tectonics and mineral resources: American Geophysical Union, Fall Meeting 2009, abstract T43C-2096.

Orris, G.J., 1986, Descriptive model of bedded barite, in Cox, D.P., and Singer, D.A., eds., Mineral occurrence models: U.S. Geological Survey Bulletin 1693, p. 216.

Orris, G.J., and Bliss, J.D., 2002, Mines and mineral occurrences of Afghanistan: United States Geological Survey Open-File Report 02-110. Available online at http://geopubs.wr.usgs.gov/openfile/of02-110/0f02-110.xls.

Peters, S.G., Ludington, S.D., Orris, G.J., Sutphin, D.M., Bliss, J.D., Rytuba, J.J., eds., and the U.S. Geological Survey-Afghanistan Ministry of Mines Joint Mineral Resource Assessment Team, 2007, Preliminary non-fuel mineral resource assessment of Afghanistan: U.S. Geological Survey Open-File Report 2007-1214, Afghanistan Geological Survey Open-File Report 2007-1214, Prepared in cooperation with the Afghanistan Geological Survey under the auspices of the U.S. Agency for International Development, U.S. Geological Survey Afghanistan Project Product No. 157, 810 p. One CD-ROM and one DVD, also available online at http://pubs.usgs.gov/of/2007/1214/.

Sborshchikov, I.M., Savostin, L.A., and Zonenshayn, L.P., 1981, Present plate tectonics between Turkey and Tibet: Tectonophysics, v. 79, no. 1-2, p. 45-73.

Shcherbina, Yu.I., Tarasenko, V.I., and Palvanov, G., 1974a, Report on the results of prospecting and evaluation implemented by the Adreskan Crew in 1972 within the copper-gold-bearing occurrence of Akhankashan: Republic of Afghanistan Ministry of Mines and Industries, Department of Mineral Survey, Kabul, report 0822, 70 p. Translated into English.

Shcherbina, Yu.I., Tarasenko, V.I., and Palvanov, G., 1974b, Report of the Adreskan crew on the results of prospecting - Evaluation work carried out within the Okhankashan copper-gold-bearing occurrence: Unpublished data on file at Republic of Afghanistan Ministry of Mines and Industries, Department of Geological and Mineral Survey, Kabul.

Stöcklin, J., 1977, Structural correlation of the Alpine ranges between Iran and Central Asia: Livre à la Mémoire d’Albert F. de Lapparent: Mémoires h. série de la Société Géologique de France, v. 8, p. 333-353.

Sutphin, D.M., Renaud, K.M., and Drew, L.J., 2011, A reevaluation of the mineral resources of the Haji-Gak iron occurrence, chap. 7D of Peters, S.G., King, T.V.V., Mack, T.J., Chornack, M.P., eds., and the U.S. Geological Survey Afghanistan Mineral Assessment Team, Summaries of important areas for mineral investment and production opportunities of nonfuel minerals in Afghanistan: U.S. Geological Survey Open-File Report 2011-1204, p. 570-597. Available at http://pubs.usgs.gov/of/2011/1204/.

Trifonov, V.G., 1978, Late Quaternary tectonic movements of western and central Asia: Geological Society of America Bulletin, v. 89, no. 7, p. 1059-1072.

Wellman, H.W., 1965, Active wrench faults of Iran, Afghanistan and Pakistan: Geologische Rundschau, v. 55, no. 3, p. 716-735. 
ISSN 2331-1258 (online)

http://dx.doi.org/10.3133/ofr20151040 